Connecticut College

Digital Commons @ Connecticut College

$3-2010$

\title{
Combining local- and large-scale models to predict the distributions of invasive plant species
}

Chad C. Jones

Connecticut College, cjones8@conncoll.edu

Steven A. Acker

Olympic National Park, Port Angeles, Washington

Charles B. Halpern

University of Washington

Follow this and additional works at: https://digitalcommons.conncoll.edu/botanyfacpub

Part of the Biodiversity Commons, Botany Commons, Other Plant Sciences Commons, and the Plant Breeding and Genetics Commons

\section{Recommended Citation}

Jones, Chad C.; Acker, Steven A.; and Halpern, Charles B., "Combining local- and large-scale models to predict the distributions of invasive plant species" (2010). Botany Faculty Publications. 5.

https://digitalcommons.conncoll.edu/botanyfacpub/5

This Article is brought to you for free and open access by the Botany Department at Digital Commons @ Connecticut College. It has been accepted for inclusion in Botany Faculty Publications by an authorized administrator of Digital Commons @ Connecticut College. For more information, please contact bpancier@conncoll.edu.

The views expressed in this paper are solely those of the author. 
RUNNING HEAD: MULTI-SCALE MODELING OF INVASIVE SPECIES

COMBINING LOCAL- AND LARGE-SCALE MODELS TO PREDICT THE DISTRIBUTIONS OF INVASIVE PLANT SPECIES

Chad C. JONEs ${ }^{1,3}$, Steven A. ACKeR ${ }^{2}$, AND Charles B. HALPERN ${ }^{1}$

${ }^{1}$ College of Forest Resources, Box 352100, University of Washington, Seattle, Washington 98195-2100 USA

${ }^{2}$ Olympic National Park, 600 East Park Avenue, Port Angeles, Washington 98362 USA

Corresponding author: Chad C. Jones, Department of Botany, Box 5398, Connecticut College, New London, CT 06320. Email: cjones8@,conncoll.edu

${ }^{3}$ Present address: Department of Botany, Box 5398, Connecticut College, New London, CT 06320. Email: cjones8@conncoll.edu 
Abstract: Habitat-distribution models are increasingly used to predict the potential distributions of invasive species and to inform monitoring. However, these models assume that species are in equilibrium with the environment, which is clearly not true for most invasive species. Although this assumption is frequently acknowledged, solutions have not been adequately addressed. There are several potential methods for improving habitat-distribution models. Models that require only presence data may be more effective for invasive species, but this assumption has rarely been tested. In addition, combining modeling types to form 'ensemble' models may improve the accuracy of predictions. However, even with these improvements, models developed for recently invaded areas are greatly influenced by the current distributions of species and thus reflect near- rather than long-term potential for invasion. Larger scale models from species' native and invaded ranges may better reflect long-term invasion potential, but they lack finer scale resolution. We compared logistic regression (which uses presence/absence data) and two presence-only methods for modeling the potential distributions of three invasive plant species on the Olympic Peninsula in Washington State, USA. We then combined the three methods to create ensemble models. We also developed climate-envelope models for the same species based on larger scale distributions and combined models from multiple scales to create an index of near- and long-term invasion risk to inform monitoring in Olympic National Park (ONP). Neither presence-only nor ensemble models were more accurate than logistic regression for any of the species. Larger scale models predicted much greater areas at risk of invasion. Our index of near- and long-term invasion risk indicates that $<4 \%$ of ONP is at high near-term risk of invasion while $67-99 \%$ of the Park is at moderate or high long-term risk of invasion. We demonstrate how modeling results can be used to guide the design of monitoring protocols and monitoring results can in turn be used to refine models. We propose that by using models from multiple scales to predict invasion risk and by explicitly linking model development to monitoring, it may be possible to overcome some of the limitations of habitatdistribution models.

Key words: Ecological Niche Factor Analysis (ENFA), Genetic Algorithm for Rule-set Prediction (GARP), Geranium robertianum, Hedera helix, Ilex aquifolium, logistic regression 


\section{INTRODUCTION}

Invasions of natural communities by exotic species are increasingly recognized as having major ecological and economic impacts (Vitousek et al. 1997, Levine et al. 2003) and as a primary factor in the loss of biological diversity (Wilcove et al. 1998). Nonnative invaders directly compete with native species for resources and can alter disturbance regimes and nutrient cycles (Mack et al. 2000). Control of invasive species is easier during the early stages of invasion (National Invasive Species Council 2001), but early detection requires extensive monitoring which can be time consuming and costly (Rew et al. 2006). It is thus necessary to prioritize and focus monitoring on areas of greatest concern (Benjamin and Hiebert 2004). To this end, habitat distribution models (HDMs) can be used to predict potentially suitable habitat for invasive species and to focus monitoring on those areas. If HDMs can accurately predict potential distributions, they can greatly benefit both monitoring and control of invasive species.

Advances in computing power and widely available environmental data have led to a proliferation of methods for creating HDMs based on known occurrences (Guisan and Zimmermann 2000, Scott et al. 2002, Elith et al. 2006). To date, however, the application of these methods to invasive species has been limited relative to other uses (Rodríguez et al. 2007, Crossman and Bass 2008). A major limitation of HDMs is the assumption that species are in equilibrium with their environments (Guisan and Zimmermann 2000). This is clearly not the case for most invasive species, which are still spreading. Thus, models based on the current distribution of a species are likely to underestimate its potential habitat (Welk 2004, Loo et al. 2007): absence may reflect either unsuitable habitat or insufficient time for dispersal (Rouget et al. 2001). Dispersal or distance from current locations can be explicitly modeled (e.g., Meentemeyer et al. 2008, Nielsen et al. 2008), but these models will still predict probability of invasion in the near term rather than suitable habitat in the longer term (Welk 2004). Most studies that apply HDMs to invasive species acknowledge this limitation, but solutions to the problem have not been adequately addressed. Several approaches are possible, however.

One possible solution is to use techniques that do not require absence data (Hirzel et al. 2002a, Tsoar et al. 2007). This approach has been used widely to model species' distributions from museum or herbarium records (Peterson 2001, Hirzel et al. 2002a), but more recently has been applied to invasive species (Anderson et al. 2006, Zhu et al. 2007). Because these methods do not include the ambiguous absence points, they may perform better than other methods for modeling the potential habitats of spreading species (Hirzel et al. 2001, Peterson 2003). The performance of presence-only methods has been compared with more traditional presenceabsence models in other ecological contexts, but only recently with invasive species (Schussman et al. 2006, Crossman and Bass 2008, Evangelista et al. 2008).

A second approach is to average the results of different models to create an 'ensemble model.' Because there is considerable variation in the performance of different model types and no consensus on the best technique, averaging the results of individual models may increase the overall accuracy of predictions (Araujo and New 2007, Crossman and Bass 2008). On the other hand, since all models are likely to suffer from the same assumption of equilibrium, combining model types may not overcome this problem.

A third potential solution to the assumption of equilibrium is to include models that are based on data from larger spatial scales or different locations. For example, habitat models can be constructed using data from a species' native range, then applied to the invaded range (e.g., Peterson 2003, Thuiller et al. 2005). Alternatively, models for invasive species developed at a continental scale may be used to predict suitable habitat in a region that has more recently been 
invaded. However, there are limitations with both of these approaches. Factors that constrain species' distributions may differ in the native and invaded ranges, leading to over- or underpredicting the potential distribution in the invaded range (Beerling et al. 1995, MacIsaac et al. 2000, Fitzpatrick et al. 2007, Loo et al. 2007). Moreover, even models developed at a continental scale may not reflect the full range of potential habitats for more than a century after the initial invasion (Welk 2004). Nevertheless, these models may provide a coarse-scale approximation of potential habitat in the region of interest and, combined with smaller-scale models, can be used to develop more efficient approaches to monitoring.

In this study we modeled the potential distributions of three invasive plant species on the Olympic Peninsula, Washington State, USA - Geranium robertianum (herb Robert), Hedera helix (English ivy), and Ilex aquifolium (English holly) — to aid in design of a monitoring plan for invasive plant species in Olympic National Park (ONP). These species were chosen because they represent a broad range of life histories and growth forms (short-lived herb, vine, and tree), they have the ability to invade undisturbed forests, and are species of concern for land managers in ONP and elsewhere in the Pacific Northwest (Boersma et al. 2005).

We developed local models using three methods based on species' current distributions on the Peninsula. These were logistic regression (LR) - the most common modeling technique, requiring presence-absence data (Manel et al. 2001) — and two presence-only techniques Genetic Algorithm for Rule-set Prediction (GARP, Stockwell and Peters 1999) and Ecological Niche Factor Analysis (ENFA, Hirzel et al. 2002a). We then averaged the results of these methods to create ensemble models. Finally, we developed larger, continental-scale, climateenvelope models for each species based on distributions in the contiguous USA (invaded range) and in Europe (native range). We addressed the following questions: (1) Do presence-only models perform better than LR when applied to invasive species? (2) Do ensemble models have higher accuracy than the individual models? (3) How can the results of models representing different spatial scales be used to guide monitoring efforts for invasive species?

\section{METHODS}

Study area

The Olympic Peninsula is located in northwestern Washington and covers an area of $\sim 12,500 \mathrm{~km}^{2}$ (Fig. 1). Olympic National Park covers $\sim 3,700 \mathrm{~km}^{2}$ at the center of the Peninsula and along the western coast. ONP contains large roadless areas with rugged terrain and undisturbed, old-growth forests. Federal, state, and private lands surround ONP; these include wilderness and areas with more extensive road networks and young to mature stands originating from decades of clearcut logging (Jenkins et al. 2003).

Elevations range from sea level to $2429 \mathrm{~m}$, with higher elevations concentrated in the Olympic Mountains at the center of the Peninsula. These mountains create a strong gradient in precipitation ranging from $709 \mathrm{~cm} / \mathrm{yr}$ along the western slopes to $63 \mathrm{~cm} / \mathrm{yr}$ in the rain shadow to the northeast. Rainfall during the growing season is relatively low with $6-12 \%$ of total precipitation falling between July and September. Mean January temperatures range from $5^{\circ} \mathrm{C}$ (at sea level) to $-9.5^{\circ} \mathrm{C}$ (on mountain peaks) and mean July temperatures from $18^{\circ} \mathrm{C}$ to $11^{\circ} \mathrm{C}$ (climate data from DAYMET: www.daymet.org, Thornton et al. 1997).

\section{Study species}

Geranium robertianum is a biennial or short-lived perennial herb that reproduces only by seeds (Tofts 2004). It grows in a wide variety of habitats, from open, rocky areas to closed forest and can tolerate a wide range of climatic and soil conditions (Tofts 2004). It is native to Europe 
and has been introduced to many other areas of the world including eastern Asia, Chile, New Zealand, Australia and the USA (Tofts 2004). It is an aggressive invader in the Pacific Northwest, where it was first observed in 1906. Geranium was first recorded at a single location on the Olympic Peninsula in the mid 1970s and has since spread (Tisch 1992). Impacts of Geranium on native vegetation have not been well studied, but it can spread rapidly and cover $50-100 \%$ of the ground surface over large areas (Tisch 1992).

Hedera helix is an evergreen vine that can grow in the open and in deep shade (Metcalfe 2005). Hedera reproduces both sexually and asexually (Grime et al. 1988); seeds can be dispersed over long distances by birds (Van Ruremonde and Kalkhoven 1991). Hedera is somewhat tolerant of both freezing and drought (Iverson 1944, Laskurain et al. 2004). Its native range extends from northern Europe to northern Africa and east to the Ukraine, but it has invaded Australia, Brazil, New Zealand, and North America (Metcalfe 2005). Hedera has been present in the Pacific Northwest since at least 1892 (Murai 1999). It was not recorded in a botanical survey of the Olympic Peninsula in 1936 (Jones 1936), but was present in 1979 (Buckingham and Tisch 1979). Hedera can form dense mats in the forest understory, reducing growth rates and density of understory herbs and tree seedlings; it also has the potential to form lianas and damage or kill mature trees (Thomas 1980, Dlugosch 2005).

Ilex aquifolium is an evergreen tree or large shrub that reproduces mainly by seeds (Peterken and Lloyd 1967). Berries can be dispersed long distances by birds (Peterken and Lloyd 1967). Ilex tolerates deep shade but also grows in the open (Peterken 1966). However, it has limited tolerance of freezing and drought (Iverson 1944, Prentice and Helmisaari 1991). Ilex is native to western Europe and mountainous areas of northern Africa and southwestern Asia (Peterken and Lloyd 1967). It is widely distributed as an ornamental tree and has become invasive in New Zealand, Australia, and northwestern USA (Weber 2003). It has been grown in the Pacific Northwest as a landscape plant and for Christmas decorations since the late 1800s (Wieman 1961). It was not found in a botanical survey of the Olympic Peninsula in 1936 (Jones 1936), but was present in 1979 (Buckingham and Tisch 1979). Little is known about the ecological impacts of Ilex on native communities. Because it is evergreen, it casts persistent shade which may reduce plant regeneration beneath its canopy (Peterken 1966).

\section{Local-scale models}

Species distributional and habitat data.- Data on the current distributions of Geranium, Hedera, and Ilex on the Olympic Peninsula were obtained from existing sources (Fig. 1, Appendix A). However, data selection was constrained by several criteria to ensure data quality: plot size between 100 and 2,500 $\mathrm{m}^{2}$, plots sampled since 1990, and plots for which all species were recorded (i.e., presence/absence data). This resulted in a total of 3,399 presence/absence data points from eight datasets including exotic species surveys, vegetation inventories, and other ecological studies. Sample sizes for individual datasets ranged from 12 to 2,832 plots. We also included 375 presence data points from five additional data sources obtained via plotless methods or small plots (e.g., exotic surveys, herbarium specimens, and personal observations). For these presence data we included records as early as 1975 because even these earlier records indicate suitable habitat. The majority of data came from ONP and Olympic National Forest.

Models incorporated 12 habitat variables, including climatic factors (number of days with frost, annual precipitation, frequency of precipitation, humidity, and incident solar radiation); topographic measures (slope, potential radiation, heat load, topographic moisture index, and distance from nearest water); and vegetation cover (conifer cover and total vegetation cover) (Appendix B). Seven additional climate and topographic variables were considered (e.g., 
elevation and temperature of the coldest month), but were not retained because of high multicollinearity $(|r|>0.8)$ with one or more of the 12 variables included (Appendix B). Climatic data were obtained from DAYMET (www.daymet.org, Thornton et al. 1997) and vegetation variables from the Interagency Vegetation Mapping Project (IVMP, www.blm.gov/or/gis/index.php). Topographic variables were based on a USGS digital elevation model. All habitat layers had a spatial resolution of $25 \mathrm{~m}$ except for climatic variables, which had $1 \mathrm{~km}$ resolution; values were applied to a $25 \mathrm{~m}$ grid by assigning each grid cell the value of the corresponding $1 \mathrm{~km}$ cell.

We tested for spatial autocorrelation by calculating Moran's I at intervals of $100 \mathrm{~m}$. Because autocorrelation was strong for all species and habitat variables at distances $<100 \mathrm{~m}$, we randomly removed points $<100 \mathrm{~m}$ from another point in the dataset. The process was implemented separately for presence and absence points for each species. This yielded 219 occurrences of Geranium (vs. 2784 absences, 7.3\% frequency), 25 of Hedera (vs. 2823 absences, $0.9 \%$ ), and 45 of Ilex (vs. 2809 absences, 1.6\%). Although numbers of occurrences are relatively low for Ilex and Hedera, other studies have found accurate model predictions using GARP with similar or smaller sample sizes (Stockwell and Peterson 2002, Pearson et al. 2007). However, LR does produce an $\sim 10 \%$ decline in accuracy at sample sizes $<100$ (Wisz et al. 2008).

Comparing model types. - We compared three approaches to modeling local distributions: LR, GARP, and ENFA. LR is a form of generalized linear modeling which can be used with presence-absence data because it produces a binomial rather than a normal distribution (Nicholls 1989). Because of the large number of predictors, we did not include quadratic or interaction terms in the models. Models were developed using S-PLUS 6.2 (Insightful 2003).

Because LR is highly sensitive to species' frequencies and model performance is poor at low frequency (Nielsen et al. 2008), we down-weighted the importance of absence points so that the total weight of presence and absence points was the same. This procedure can reduce bias in LR when the percentage of occurrences is low (Maggini et al. 2006). We started with all 12 habitat variables and removed them in stepwise fashion using the step function in S-PLUS. Removals were based on reductions in Akaike's Information Criterion (AIC) - a measure which combines model simplicity and goodness of fit (Crawley 2002). The resulting regression equations (reduced models) were then used to predict the habitat suitability of each grid cell in the study area. Suitability scores ranged from 0 to 1 , but were rescaled to 0 to 100 for comparability with GARP and ENFA.

GARP is an artificial-intelligence based modeling system (Stockwell and Peters 1999). It requires only presence data and uses a combination of rules to predict presence or absence for each grid cell. GARP has recently been used to model the potential distributions of invasive species (e.g., Underwood et al. 2004, Anderson et al. 2006). Because it requires only presence data and includes interactions among variables (Stockwell and Peters 1999), it may perform better than LR for invasive species. For this study, we used DesktopGARP 1.1.6 (http://nhm.ku.edu/desktopgarp/index.html). We used all rule types and all 12 habitat variables. Because there is a random element to the model, each model run produces a somewhat different result. For each species we created 100 GARP models, then computed for each grid cell a habitat suitability score (0-100, equal to the number of model runs predicting presence).

ENFA is akin to principal components analysis in that it reduces a larger number of environmental predictors (that may be correlated) to fewer factors that are uncorrelated (Hirzel et al. 2002a). Similar to GARP, this technique does not require absence data. Using simulated data, ENFA performed better than LR for a species with an expanding range (Hirzel et al. 2001); 
thus, ENFA may work well for invasive species. Each cell in the landscape is given a score for each factor based on its similarity in that factor to locations at which the species is present. Scores are combined for all significant factors, then standardized to create a habitat-suitability score (0 to 100). We created ENFA models for each species with Biomapper 3.0 (Hirzel et al. $2002 \mathrm{~b}$ ), using the median distance measure and a broken-stick model to determine the number of factors to include (Hirzel et al. 2002a).

Comparing model performance.- Model performance may be judged by accuracy (ability to predict species presence or absence) and by agreement (consistency given different sets of input data). To assess accuracy and agreement, presence and absence data for each species were partitioned into five equal subsets. For each modeling technique five replicate models were run for each species; each run used $80 \%$ of the data with a different set of $20 \%$ reserved to test performance.

Most measures of model accuracy require predictions of presence/absence at each point in the landscape (Fielding and Bell 1997); predicted values are then compared to empirical data not used in model construction (in our case, $20 \%$ of points). However, models in the current study produce habitat-suitability scores (0-100), not binary responses. This requires selection of a threshold score or value above which the model is considered to predict presence (Fielding and Bell 1997). Typically a value of 50 has been selected (Fielding and Bell 1997), although any value can be used. Rather than arbitrarily set a threshold, we used an approach that maximized model accuracy, as described below. Two measures of accuracy were considered.

The first, the true skill statistic (TSS), is similar to the Kappa statistic, a commonly used threshold-dependent measure of model accuracy (Fielding and Bell 1997). Kappa reflects the rate of false positive and false negative predictions, but is sensitive to frequency of presence points (Welk 2004). TSS is equivalent to Kappa when frequencies of presence and absence points are equal, but it is not sensitive to frequency (Allouche et al. 2006). TSS is calculated as Sensitivity + Specificity - 1 where:

$$
\begin{aligned}
& \text { Sensitivity }=a /(a+c) \\
& \text { Specificity }=d /(b+d)
\end{aligned}
$$

and $a$ is number of true positives, $b$ is number of false positives, $c$ is number of false negatives and $d$ is number of true negatives. Values $>0.6$ are considered good, 0.2-0.6 fair to moderate, and $<0.2$ poor (Landis and Koch 1977). To identify the suitability score used as the threshold for predicting presence, we calculated TSS for each model replicate across the full range of possible threshold values (0-100) and selected the threshold that maximized TSS. This method provides an optimal threshold for evaluating the accuracy of each model replicate (Robertson et al. 2004), thus each replicate may have a different threshold.

We also assessed accuracy with Receiver Operating Characteristic (ROC) plots, which do not require selection of a habitat-suitability threshold (Fielding and Bell 1997). ROC plots display the relationship between Sensitivity (proportion of true positives accurately predicted by a model) and 1 - Specificity (proportion of true negatives accurately predicted by a model) over a range of threshold values (0-100). An ROC plot produces an asymptotically ascending curve with the area under the curve (AUC) used as a measure of model accuracy (Fielding and Bell 1997). Values of AUC generally range from 0.5 (equivalent to that due to chance), to 1.0 (perfect performance). Values $>0.9$ are considered good, 0.7-0.9 moderate, and $<0.7$ poor (Pearce and Ferrier 2000).

To assess agreement among model replicates, we used the Kappa statistic. In this context, Kappa measured consistency among the five replicates of each model type (Monserud and 
Leemans 1992) rather than model accuracy. For each species, we calculated Kappa for all possible pairs of model replicates ( $n=10$ comparisons).

Finally, for each species and model replicate, we calculated two measures of habitat suitability: mean suitability among grid cells and percentage of habitat predicted as suitable (percent suitable habitat) for the threshold value that maximized TSS (accuracy).

To test whether presence-only models (GARP and ENFA) performed better than LR (question 1), we used a series of one-way ANOVA tests to compare accuracy (TSS and AUC), agreement (Kappa), mean suitability, and percent suitable habitat among model types for each species. ANOVA tests that proved significant $(p \leq 0.05)$ were followed by Bonferroni post-hoc tests of means (SPSS 2006).

To evaluate model results and the predicted distributions of suitable habitat, we assessed the relative (qualitative) importance of habitat variables in each model type. Different metrics were needed for each model type. For LR we used the number of replicates in which a variable was retained after stepwise removal. There is no intrinsic method in GARP to assess the relative importance of habitat variables, thus we adapted the post-hoc method used by Loo et al. (2007). For each replicate model, we created 50 GARP models with each of the 12 habitat variables removed (600 models/replicate). We used $t$-tests to compare the accuracy (Sensitivity) of models that included the variable of interest (550 models/replicate) with those in which the variable was removed (50 models/replicate); we then averaged the $t$-statistic for the five replicate models of each species. The magnitude of a positive mean $t$-statistic reflected the degree to which a variable improved model accuracy. For ENFA, variable loadings on the first factor (i.e., marginality) served as measures of how different a species' occurrence was from the median values of the variables in the study area.

\section{Ensemble models}

For each species we created ensemble models by averaging among model types the habitatsuitability scores (0-100) of each grid cell. We calculated an average for each of the five replicates (i.e., the same $80 \%$ of the data for each model type). To test whether ensemble models performed better than individual model types (question 2), we used two-sample $t$ tests $(n=5$; SPSS 2006) to compare model accuracy (TSS and AUC) and agreement (Kappa) between the ensemble model and the individual model type with greatest accuracy or agreement.

\section{Continental-scale, climate-envelope models}

We developed two types of continental-scale, climate-envelope models based on species' distributions in the contiguous USA (hereafter 'invaded-range' models) and in the native range (hereafter 'native-range' models). Data on species presence for invaded-range models were derived from the literature, herbarium specimens, and personal communications (Jones and Reichard 2009). Data on species presence for native-range models were taken from the Global Biodiversity Information Facility (www.gbif.org), using only points with an accuracy of $<1 \mathrm{~km}$. Three climatic variables were used: mean temperature of the coldest month, mean temperature of the warmest month, and annual precipitation. These variables were chosen because they typically show strong correlations with plant distributions at large spatial scales (Cramer and Prentice 1988, Shafer et al. 2001). Sources of climatic data were DAYMET (Thornton et al. 1997) for invaded-range models and WORLDCLIM (www.worldclim.org) for native-range models.

Climate-envelope models were constructed using a procedure similar to that in BIOCLIM 
(Busby 1991). Predicted distributional limits were set at the extreme values of each climatic variable based on species presence, however, to reduce the influence of outliers, we first removed the $5 \%$ most extreme values for each variable $(2.5 \%$ on each end of the distribution; Appendix C). Native- and invaded-range models were applied to the Olympic Peninsula by overlaying predictions of suitable habitat on the study area. Any $25 \mathrm{~m}$ grid cell on the Peninsula with climatic conditions deemed suitable in the invaded- or native-range was identified as suitable. For both types of models we calculated the percentage of cells predicted to be suitable habitat (percent suitable habitat), Sensitivity (proportion of true positives accurately predicted by a model), and TSS (accuracy as defined earlier for local models).

\section{Combining models from multiple scales to inform monitoring}

Local-scale models are sensitive to the current distributions of species and are more likely to reflect risk of invasion in the near term. In contrast, continental-scale (native- and invadedrange) models predict the climatic suitability of habitats at considerably larger scales and thus reflect the climatic potential of species independent of dispersal. We combined the predictions of both types of models to characterize both near- and long-term risk of invasion with the ultimate goal of improving efficacy of monitoring in Olympic National Park (question 3).

First, for each grid cell we tallied the number of replicate runs of the three local-scale models that predicted suitability given the threshold value that maximized accuracy; values could range from 0 to15. For simplicity, we classified cells with values of 0 as 'minimal risk' of nearterm invasion, 1-5 as 'low risk,' 6-10 as 'moderate risk,' and $>10$ as 'high risk.' Next, using continental-scale models we classified each grid cell as having (1) high long-term risk of invasion if it was suitable in both native- and invaded-range models, (2) moderate risk if suitable in one of the two models, and (3) minimal risk if suitable in neither model. We then merged the results of these two classification schemes to assign each grid cell to one of 12 possible combinations of near- and long-term risk of invasion.

\section{RESULTS}

\section{Comparison of logistic regression and presence-only models}

In general, suitable habitat was predicted to occur at low elevations around the edges of the Olympic Peninsula and in river valleys extending to its center. For Geranium, suitable habitat was concentrated along the northern coast where the species first invaded (Fig. 2). For Hedera and Ilex, suitable habitat was distributed on all sides of the Peninsula (Figs. 3 and 4).

Among local-scale models, ENFA consistently had the lowest mean suitability scores, whereas GARP tended to have the highest (Fig. 5a). The relative performance of models was very different, however, for predictions of percent suitable habitat (Fig. 5b). This disparity was due, in part, to the selection of very different threshold values (Fig. $5 \mathrm{c}$ ) to maximize model accuracy. Among species and model types, percent suitable habitat ranged from $9.2 \%$ (Geranium, GARP) to $31.8 \%$ (Hedera, GARP) (Fig. 5b).

For none of the species or measures of model accuracy (AUC or TSS) were presence-only models more accurate than LR (Figs. 6a, b). More often, model accuracy was greater for LR than GARP and/or ENFA. Similarly, presence-only models did not show greater agreement (consistency among replicates) than LR (Fig. 6c); values for LR were comparable to those of GARP and better than those of ENFA for Geranium and Hedera.

The importance of particular habitat variables differed among modeling methods and species (Appendix D). Nevertheless, some patterns were apparent. Number of frost days was important in LR and ENFA models for all species and for Hedera in GARP models: it was negatively 
associated with species presence in all cases (except LR for Geranium). Annual precipitation and precipitation frequency were important for most species in all three model types. In ENFA, species occurred in areas of low annual precipitation and low precipitation frequency. In LR however, coefficients were positive for one of these variables for both Geranium and Ilex due to multicollinearity. Conifer cover and distance from water were important in LR and ENFA models for Geranium; both were negatively associated with Geranium occurrence.

\section{Ensemble models}

The accuracy of ensemble models was no greater than the accuracy of the best-performing individual model (LR in all cases; Figs. 6a, b). For only one of six tests did accuracy differ significantly (LR $>$ ensemble model for Ilex based on AUC; $t=3.19, P=0.012$ ). Agreement (consistency among replicates) for ensemble models was comparable to LR for Geranium and Hedera, but significantly lower than LR for Ilex $(t=3.47, P=0.003)$.

\section{Continental-scale models}

Invaded-range models predicted that $52-59 \%$ of the Peninsula is suitable for invasion (Table 1), much greater than that predicted by the local-scale models (ca. 9-32\%). Native-range models predicted even greater suitability (86-99\%). For all three species, models consistently predicted suitable habitat in low elevation areas around the perimeter of the Peninsula, but models differed in how far (high) into the mountains suitable habitat extended (Figs. 2d, 3d, and 4d).

Almost all locations where species currently occur were predicted as suitable habitat by both types of continental-scale models (Sensitivity values of 0.90-1.00; Table 1). However, both types of models predicted suitability in many areas where the species do not occur; thus, model accuracy was poor to fair (TSS values of 0.00-0.47; Table 1).

\section{Combining models from multiple scales}

Most (>92\%) of the cells classified as moderate or high risk in the near term (local-scale models) were classified as high risk in the longer term (continental-scale models). Likewise, areas with low risk in the long term all had minimal risk in the near term. Thus, from 12 possible categories of combined risk, we were able to place all cells into one of five categories (Table 2): minimal risk (habitat unsuitable based on all models); low near-term, but moderate long-term risk; low near-term, but high long-term risk; moderate near-term, but high long-term risk; high near-term and high long-term risk.

For all three species, $<15 \%$ of the Peninsula was classified as minimal risk for invasion; in contrast, ca. 19-36\% was classified as moderate or high near-term risk (Table 2; Fig. 7). The majority of the area with high near-term risk, however, was outside ONP. Within ONP, moderate and high near-term risk constituted $<8.3 \%$ of the total area (Table 2 ) and was concentrated in large river valleys (Fig. 7).

\section{DISCUSSION}

Despite theoretical reasons why presence-only models should perform better than logistic regression for species that are spreading (Hirzel et al. 2001, Peterson 2003), both presence-only techniques (GARP and ENFA) consistently underperformed in this study. Presence-only models were no more (or sometimes less) accurate and were equally or more variable than LR.

Although both GARP (Peterson et al. 2003, Anderson et al. 2006, Zhu et al. 2007) and LR (Buchan and Padilla 2000, Nielsen et al. 2008) have been used to model the distributions of invasive species, few studies have compared presence-only and LR models in this context, and 
with mixed results. Schussman et al. (2006) found that LR was much more accurate in predicting the current distribution of an invasive grass in Arizona, but Crossman and Bass (2008) found that GARP was more accurate for an invasive tree in southern Australia.

It is becoming increasingly clear that model types can vary markedly in performance (Pearson et al. 2006), depending on characteristics of the species and habitat data (Segurado and Araujo 2004). Given the variation among model types, and the dependence of models on species traits and spatial distributions (Evangelista et al. 2008), it is not possible to identify a modeling technique that is optimal in all situations (Pearson et al. 2006). One potential solution to this problem is to combine different types of models to create an ensemble, or average model (Araujo and New 2007).

We found that ensemble models were no more accurate than LR. This result contrasts with that of Crossman and Bass (2008), who found that averaging the predictions of all models led to increased accuracy. We conclude that ensemble models may be useful in some, but not all situations. Their performance may also improve by including a larger number of component models. Studies of a diversity of species and systems are needed to identify the conditions under which ensemble modeling is advantageous. Combining models in this way does have the advantage of providing a single prediction of habitat suitability, but it also results in the loss of information associated with individual model types.

Despite their potential advantages, ensemble models are susceptible to the same problems that limit the individual models from which they are built. First, methods used to assess model performance test the ability to predict current, rather than potential, distributions of invasive species. A model that accurately predicts the current distribution may not accurately predict the potential distribution (Pearson et al. 2006). Conversely, models that are less accurate in predicting current distributions may be more accurate in predicting future distributions. In our study, GARP was less accurate than LR, however visual examination of model results suggests that GARP may more accurately predict potential distributions. For example, Geranium robertianum has been observed increasingly along the western edge of the Peninsula (C. Lucero, Clallam County Weed Board, personal communication) although there were few such georeferenced locations in our study. Compared to LR, GARP predicted that more of the western edge of the Peninsula is suitable habitat for Geranium.

One factor that may contribute to the disparity between predictions of current and potential distributions is that indices of accuracy such as AUC and TSS give equal weight to false positives and false negatives. For invasive species, however, false negatives are more problematic; false positives may simply reflect insufficient time to disperse rather than unsuitable habitat (Pearson et al. 2006). Because of this equal weighting and the use of thresholds that maximize accuracy, GARP, and to a lesser extent, other models, greatly reduced the amount of habitat predicted to be suitable. Techniques for differential weighting of false positives and false negatives are available, but the methods for weighting are subjective (Liu et al. 2005).

A second major limitation of individual and ensemble models is that their predictions are influenced by invasion patterns. All share the basic assumption that species are at equilibrium with the environment, which is not true for spreading species such as these. The distributions of these species during early stages of invasion are shaped by both dispersal patterns and habitat requirements, as are model predictions. This limitation is often exacerbated by bias in the sampling distribution. Most sample locations in our data sources (as in other studies) were along roads, trails, or rivers, where invasions are first expected to occur. As a consequence, predicted 
habitat is more likely to occur near these features simply as a result of the distribution of data points. Habitats predicted to be suitable will be similar to those first invaded and, because of autocorrelation of habitat variables, these will be concentrated close to currently invaded areas. Thus model predictions reflect areas likely to be invaded in the near-term. Several studies have acknowledged this issue by explicitly incorporating dispersal or spatial autocorrelation into predictive models (Meentemeyer et al. 2008, Nielsen et al. 2008). Even if dispersal is not explicitly considered, it can affect predictions because of spurious correlations with environmental variables (Anderson et al. 2006).

We found evidence of such correlations in our study. Geranium robertianum first invaded the Olympic Peninsula on the north coast, near Port Angeles (Tisch 1992), where it is most common (Fig. 2). Although it continues to spread, occurrences decrease to the southwest resulting in a negative association with annual precipitation which is lowest near Port Angeles (Appendix D). There is no evidence that Geranium is restricted to drier climates in its global distribution (e.g., climate-envelope models suggest that it can occur in the wettest areas of the Peninsula). Thus, the concentration of predicted suitable habitat in the northern part of the Peninsula likely reflects invasion patterns rather than habitat requirements. This confirms the prediction that local-scale models reflect near-term invasion risk regardless of whether they explicitly include dispersal variables.

By employing predictive models that operate at a range of spatial scales it is possible to overcome some of these limitations. Models at each scale have different limitations; thus, combining information from multiple scales can improve predictive power (Ibanez et al. 2009). This approach has been used to understand the factors that affect species' distributions (Pearson et al. 2004, Nielsen et al. 2008), but only recently as a method to improve model predictions (Ibanez et al. 2009).

Continental-scale models from the native and invaded ranges can be used to define the bounds of climatically suitable habitats within a region. At large scales, climate is a primary determinant of species' invasions (Milbau et al. 2009). In this study, continental-scale (climateenvelope) models correctly predicted nearly all occurrences of the three species on the Peninsula (Sensitivity values $\geq 0.9$ ) and predicted that none are likely to establish at high elevations where winter temperatures are too low. Only the native-range model for Geranium predicted suitability at high elevations. This climatic limitation is confirmed by the importance of number of frost days in the local-scale models. Continental-scale models also suggest that the restriction of Geranium to drier parts of the Peninsula, as predicted by local-scale models, does not reflect a climatic limitation, but an artifact of invasion history.

Although continental-scale models can define the climatic limits of invasive species, localscale models provide additional insights into their potential distributions at finer resolution. Climate is less important in shaping invasion patterns at smaller spatial scales-the scales at which topography, land cover, and disturbance are more important (Milbau et al. 2009). Invasion history can also play an important role at these scales. Local-scale models, that can more easily incorporate these factors, better elucidate small-scale distributional patterns. This was evident in our study, both in the influence of invasion history on local-scale models and by the association of Geranium with low conifer cover and proximity to water.

Combining models from different scales can also be useful in monitoring. Continental-scale models can be combined with finer scale models of current distributions to create a hierarchical framework of invasion risk that reflects the hierarchical nature of the factors controlling invasions (Milbau et al. 2009). A simple scheme for classifying near- and long-term risk of 
invasion can then be used to guide monitoring efforts.

\section{Developing a monitoring protocol for Olympic National Park}

Monitoring for invasive species is time consuming and costly, particularly over large areas (Rew et al. 2006). Because risk of invasion varies spatially, models can be used to focus monitoring on areas of greatest risk. Monitoring is typically focused on areas where dispersal is likely (e.g., along roads, trails, and rivers) with little regard for habitat conditions. Predictive models can be used to improve these methods by incorporating habitat suitability into modeling design. Although most new occurrences are likely to be in close proximity to roads or existing populations, more distant establishment events are more important to detect. Habitat distribution models can be used to determine which of these more distant areas are climatically suitable and should be monitored.

The species in this study, and others, are in the early stages of invasion in Olympic National Park, thus predictive models have the potential to inform programs of early detection and control at a time when such efforts may still be effective. Although the intent to inform monitoring has been a general goal of habitat distribution models (e.g., Anderson et al. 2006, Crossman and Bass 2008), most models have not been explicitly linked to the design of a monitoring protocol. Our classification of near- and long-term invasion risk in ONP provides a simple framework for designing a spatially explicit monitoring plan that draws directly from the predictions of localand continental-scale models. Degree (low to high) and time frame of risk (near- and long-term) serve as logical criteria for establishing the spatial intensity and frequency of monitoring efforts. Areas classified as high near-term risk would receive the greatest intensity (density of effort) and frequency of monitoring. These areas were considered suitable habitat in most or all of the models. Areas of high risk are most similar, and typically closest, to areas of the Peninsula that have already been invaded. Fortunately, $<4 \%$ of ONP is classified as high risk for all of the species considered, and these areas are in lowland river valleys, close to roads and trails. In areas with lower risk of invasion, intensity and/or frequency of monitoring can be reduced.

In areas with minimal risk (which, for Ilex and Hedera, constitute more than a third of ONP), monitoring can occur at low intensity and frequency. Nevertheless, some monitoring should still occur in these areas for two reasons. First, it can be used to test model predictions; if species establish in areas of minimal risk, it may suggest a problem with current models. Second, model predictions are based on the current climate. As climate warms, species may spread to higher elevations than predicted, thus models will need to be modified (Guisan and Thuiller 2005). One way to adapt models to a changing climate is to adjust climate layers to account for predicted changes in temperature and related variables. Monitoring in areas of minimal risk will allow detection of shifts in species' distributions in response to climate change.

A major goal of invasive species modeling is to aid in early detection and long-term monitoring; however, for models to be useful for management, we suggest that modeling and monitoring need to be more closely integrated. Models can assist land managers in targeting scarce resources to areas of high risk. In turn, when monitoring strategies are guided by predictions of invasion risk, results of monitoring can be used to refine model assumptions and techniques. This iterative approach will increase our understanding of how well models can predict the future distributions of invasive species. Given the limitations of existing models and our inability to assess the accuracy of predictions of future distributions, explicit and dynamic links between modeling and monitoring are critical. 
Models that use only presence data and ensemble models that average the results of multiple model types have been proposed as methods to improve predictions of the potential distributions of invasive species. We found that neither approach improved accuracy in predicting the current distributions of Geranium robertianum, Hedera helix, or Ilex aquifolium on the Olympic Peninsula. Presence-only models (ENFA and GARP) were less accurate and ensemble models were no more accurate than logistic regression. However, current accuracy indices assess accuracy relative to current distributions; presence-only models may better predict potential distributions, but it is not possible to verify this (at least in the short term). In addition, models based on data from an invaded region are sensitive to the current spatial distributions of species. Given these challenges, it is important to consider model results critically. Combining models that represent different spatial scales may overcome some of these challenges; they can provide insights into current and future risks of invasion and help to set priorities for monitoring. Modeling and monitoring can also be used iteratively to test and refine predictions about, and monitor changes in, species' distributions.

\section{ACKNOWLEDGMENTS}

We thank Collette DeFerrari, Ann Lezberg, Robin Lesher, Ed Schreiner, Andrea Woodward, Dan Campbell and staff at Olympic National Park and Olympic National Forest for sharing data for this project. Katherine Beirne provided assistance with GIS layers. Members of the Halpern lab group provided critical feedback on many elements of this work. We appreciate the constructive comments of two anonymous referees. Funding was provided by the National Park Service and U.S. Geological Survey (task agreement no. J9W88040007) implemented through cooperative agreement with Pacific Northwest Cooperative Ecosystems Study Unit (agreement no. CA9088A0008).

\section{LiTERATURE CITED}

Allouche, O., A. Tsoar, and R. Kadmon. 2006. Assessing the accuracy of species distribution models: prevalence, kappa and the true skill statistic (TSS). Journal of Applied Ecology 43:1223-1232.

Anderson, R. P., A. T. Peterson, and S. L. Egbert. 2006. Vegetation-index models predict areas vulnerable to purple loosestrife (Lythrum salicaria) invasion in Kansas. Southwestern Naturalist 51:471-480.

Araujo, M. B., and M. New. 2007. Ensemble forecasting of species distributions. Trends in Ecology and Evolution 22:42-47.

Beerling, D. J., B. Huntley, and J. P. Bailey. 1995. Climate and the distribution of Fallopia japonica - use of an introduced species to test the predictive capacity of response surfaces. Journal of Vegetation Science 6:269-282.

Benjamin, P., and R. Hiebert. 2004. Assessing the invasive plant issue. Park Science 22:27-31. Boersma, P. D., S. H. Reichard, and A. N. Van Buren, editors. 2005. Invasive species in the Pacific Northwest. University of Washington Press, Seattle, Washington, USA.

Buchan, L. A. J., and D. K. Padilla. 2000. Predicting the likelihood of Eurasian watermilfoil presence in lakes, a macrophyte monitoring tool. Ecological Applications 10:1442-1455.

Buckingham, N. M., and E. L. Tisch. 1979. Vascular plants of the Olympic Peninsula. NPS Cooperative Park Studies Unit Report B-79-2, Seattle, Washington, USA. 
Busby, J. R. 1991. BIOCLIM - a bioclimatic analysis and prediction system. Pages 64-68 in C.

R. Margules and M. P. Austin, editors. Nature conservation: cost effective biological surveys and data analysis. CSIRO, Melbourne, Australia.

Cramer, W., and I. C. Prentice. 1988. Simulation of regional soil moisture deficits on a European scale. Norsk Geografisk Tidsskrift 42:149-151.

Crawley, M. J. 2002. Statistical computing: an introduction to data analysis using S-plus. John Wiley and Sons, Chichester, UK.

Crossman, N. D., and D. A. Bass. 2008. Application of common predictive habitat techniques for post-border weed risk management. Diversity and Distributions 14:213-224.

Dlugosch, K. M. 2005. Understory community changes associated with English ivy invasions in Seattle's urban parks. Northwest Science 79:52-59.

Elith, J., C. H. Graham, R. P. Anderson, M. Dudik, S. Ferrier, A. Guisan, R. J. Hijmans, F. Huettmann, J. R. Leathwick, A. Lehmann, J. Li, L. G. Lohmann, B. A. Loiselle, G. Manion, C. Moritz, M. Nakamura, Y. Nakazawa, J. M. Overton, A. T. Peterson, S. J. Phillips, K. Richardson, R. Scachetti-Pereira, R. E. Schapire, J. Soberon, S. Williams, M. S. Wisz, and N. E. Zimmermann. 2006. Novel methods improve prediction of species' distributions from occurrence data. Ecography 29:129-151.

Evangelista, P. H., S. Kumar, T. J. Stohlgren, C. S. Jarnevich, A. W. Crall, J. B. Norman, and D. T. Barnett. 2008. Modelling invasion for a habitat generalist and a specialist plant species. Diversity and Distributions 14:808-817.

Fielding, A. H., and J. F. Bell. 1997. A review of methods for the assessment of prediction errors in conservation presence/absence models. Environmental Conservation 24:38-49.

Fitzpatrick, M. C., J. F. Weltzin, N. J. Sanders, and R. R. Dunn. 2007. The biogeography of prediction error: why does the introduced range of the fire ant over-predict its native range? Global Ecology and Biogeography 16:24-33.

Grime, J. P., J. G. Hodgson, and R. Hunt. 1988. Comparative plant ecology: a functional approach to common British species. Unwin Hyman, London, UK.

Guisan, A., and W. Thuiller. 2005. Predicting species distribution: offering more than simple habitat models. Ecology Letters 8:993-1009.

Guisan, A., and N. E. Zimmermann. 2000. Predictive habitat distribution models in ecology. Ecological Modelling 135:147-186.

Hirzel, A. H., J. Hausser, D. Chessel, and N. Perrin. 2002a. Ecological-niche factor analysis: How to compute habitat-suitability maps without absence data? Ecology 83:2027-2036. Hirzel, A. H., J. Hausser, and N. Perrin. 2002b. Biomapper 3.0. Laboratory for Conservation Biology, University of Lausanne, Lausanne, Switzerland.

Hirzel, A. H., V. Helfer, and F. Metral. 2001. Assessing habitat-suitability models with a virtual species. Ecological Modelling 145:111-121.

Ibanez, I., J. A. Silander, A. M. Wilson, N. LaFleur, N. Tanaka, and I. Tsuyama. 2009. Multivariate forecasts of potential distributions of invasive plant species. Ecological Applications 19:359-375.

Insightful. 2003. S-PLUS 6.2. Insightful Corporation, Seattle, Washington, USA. Iverson, J. 1944. Viscum, Hedera and Ilex as climate indicators. Geologiska Föreningens I Stockholm Förhandlingar 66:463-483.

Jenkins, K., A. Woodward, and E. G. Schreiner. 2003. A framework for long-term ecological monitoring in Olympic National Park: prototype for the coniferous forest biome. U.S. 
Geological Survey, Biological Resources Discipline, Information and Technology Report, USGS/BRD/ITR-2003-2006.

Jones, C. C., and S. H. Reichard. 2009. Current and potential distributions of three non-native invasive plants in the contiguous USA. Natural Areas Journal, in press.

Jones, G. N. 1936. A botanical survey of the Olympic Peninsula, WA. University of Washington Press, Seattle, Washington, USA.

Landis, J. R., and G. G. Koch. 1977. The measurement of observer agreement for categorical data. Biometrics 33:159-174.

Laskurain, N. A., A. Escudero, J. M. Olano, and J. Loidi. 2004. Seedling dynamics of shrubs in a fully closed temperate forest: greater than expected. Ecography 27:650-658.

Levine, J. M., M. Vila, C. M. D'Antonio, J. S. Dukes, K. Grigulis, and S. Lavorel. 2003. Mechanisms underlying the impacts of exotic plant invasions. Proceedings of the Royal Society of London Series B 270:775-781.

Liu, C. R., P. M. Berry, T. P. Dawson, and R. G. Pearson. 2005. Selecting thresholds of occurrence in the prediction of species distributions. Ecography 28:385-393.

Loo, S. E., R. MacNally, and P. S. Lake. 2007. Forecasting New Zealand mudsnail invasion range: model comparison using native and invaded ranges. Ecological Applications 17:181189.

MacIsaac, H. J., H. A. M. Ketelaars, I. A. Grigorovich, C. W. Ramcharan, and N. D. Yan. 2000. Modeling Bythotrephes longimanus invasions in the Great Lakes basin based on its European distribution. Archiv fuer Hydrobiologie 149:1-21.

Mack, R. N., D. Simberloff, W. M. Lonsdale, H. Evans, M. Clout, and F. A. Bazzaz. 2000. Biotic invasions: causes, epidemiology, global consequences and control. Ecological Applications 10:689-710.

Maggini, R., A. Lehmann, N. E. Zimmermann, and A. Guisan. 2006. Improving generalized regression analysis for the spatial prediction of forest communities. Journal of Biogeography 33:1729-1749.

Manel, S., H. C. Williams, and S. J. Ormerod. 2001. Evaluating presence-absence models in ecology: the need to account for prevalence. Journal of Applied Ecology 38:921-931.

Meentemeyer, R. K., B. L. Anacker, W. Mark, and D. M. Rizzo. 2008. Early detection of emerging forest disease using dispersal estimation and ecological niche modeling. Ecological Applications 18:377-390.

Metcalfe, D. J. 2005. Hedera helix L. Journal of Ecology 93:632-648.

Milbau, A., J. C. Stout, B. J. Graae, and I. Nijs. 2009. A hierarchical framework for integrating invasibility experiments incorporating different factors and spatial scales. Biological Invasions 11:941-950.

Monserud, R. A., and R. Leemans. 1992. Comparing global vegetation maps with the Kappa statistic. Ecological Modelling 62:275-293.

Murai, M. 1999. Understanding the invasion of Pacific Northwest forests by English ivy (Hedera spp., Araliaceae). M.S. Thesis, University of Washington, Seattle, Washington, USA.

National Invasive Species Council. 2001. Meeting the invasive species challenge: national invasive species management plan. National Invasive Species Council, Washington DC, USA.

Nicholls, A. O. 1989. How to make biological surveys go further with generalized linear models. Biological Conservation 50:51-75. 
Nielsen, C., P. Hartvig, and J. Kollmann. 2008. Predicting the distribution of the invasive alien Heracleum mantegazzianum at two different spatial scales. Diversity and Distributions 14:307-317.

Pearce, J., and S. Ferrier. 2000. Evaluating the predictive performance of habitat models developed using logistic regression. Ecological Modelling 133:225-245.

Pearson, R. G., T. P. Dawson, and C. Liu. 2004. Modelling species distributions in Britain: a hierarchical integration of climate and land-cover data. Ecography 27:285-298.

Pearson, R. G., C. J. Raxworthy, M. Nakamura, and A. T. Peterson. 2007. Predicting species distributions from small numbers of occurrence records: a test case using cryptic geckos in Madagascar. Journal of Biogeography 34:102-117.

Pearson, R. G., W. Thuiller, M. B. Araujo, E. Martinez-Meyer, L. Brotons, C. McClean, L. Miles, P. Segurado, T. P. Dawson, and D. C. Lees. 2006. Model-based uncertainty in species range prediction. Journal of Biogeography 33:1704-1711.

Peterken, G. 1966. Mortality of holly (Ilex aquifolium) seedlings in relation to natural regeneration in the New Forest. Journal of Ecology 54:259-269.

Peterken, G. F., and P. S. Lloyd. 1967. Biological flora of the British Isles. Ilex aquifolium L. Journal of Ecology 55:841-858.

Peterson, A. T. 2001. Predicting species' geographic distributions based on ecological niche modeling. Condor 103:599-605.

Peterson, A. T. 2003. Predicting the geography of species' invasions via ecological niche modeling. Quarterly Review of Biology 78:419-433.

Peterson, A. T., M. Papes, and D. A. Kluza. 2003. Predicting the potential invasive distributions of four alien plant species in North America. Weed Science 51:863-868.

Prentice, I. C., and H. Helmisaari. 1991. Silvics of North European trees - compilation, comparisons and implications for forest succession modeling. Forest Ecology and Management 42:79-93.

Rew, L. J., B. D. Maxwell, F. L. Dougher, and R. Aspinall. 2006. Searching for a needle in a haystack: evaluating survey methods for non-indigenous plant species. Biological Invasions 8:523-539.

Robertson, M. P., M. H. Villet, and A. R. Palmer. 2004. A fuzzy classification technique for predicting species' distributions: applications using invasive alien plants and indigenous insects. Diversity and Distributions 10:461-474.

Rodríguez, J. P., L. Brotons, J. Bustamante, and J. Seoane. 2007. The application of predictive modelling of species distribution to biodiversity conservation. Diversity and Distributions 13:243-251.

Rouget, M., D. M. Richardson, S. J. Milton, and D. Polakow. 2001. Predicting invasion dynamics of four alien Pinus species in a highly fragmented semi-arid shrubland in South Africa. Plant Ecology 152:79-92.

Schussman, H., E. Geiger, T. Mau-Crimmins, and J. Ward. 2006. Spread and current potential distribution of an alien grass, Eragrostis lehmanniana Nees, in the southwestern USA: comparing historical data and ecological niche models. Diversity and Distributions 12:582592.

Scott, J. M., P. J. Heglund, M. L. Morrison, J. B. Haufler, M. G. Raphael, and W. A. Wall, editors. 2002. Predicting species occurrences: issues of accuracy and scale. Island Press, Washington DC, USA. 
Segurado, P., and M. B. Araujo. 2004. An evaluation of methods for modelling species distributions. Journal of Biogeography 31:1555-1568.

Shafer, S. L., P. J. Bartlein, and R. S. Thompson. 2001. Potential changes in the distributions of western North America tree and shrub taxa under future climate scenarios. Ecosystems 4:200-215.

SPSS. 2006. SPSS 15.0 for Windows. SPSS Inc., Chicago, Illinois, USA.

Stockwell, D., and D. Peters. 1999. The GARP modelling system: problems and solutions to automated spatial prediction. International Journal of Geographical Information Science 13:143-158.

Stockwell, D. R. B., and A. T. Peterson. 2002. Effects of sample size on accuracy of species distribution models. Ecological Modelling 148:1-13.

Thomas, L. K. J. 1980. The impact of three exotic plant species on a Potomac island. U.S. Department of the Interior, Washington DC, USA.

Thornton, P. E., S. W. Running, and M. A. White. 1997. Generating surfaces of daily meteorological variables over large regions of complex terrain. Journal of Hydrology 190:214-251.

Thuiller, W., D. M. Richardson, P. Pysek, G. F. Midgley, G. O. Hughes, and M. Rouget. 2005. Niche-based modelling as a tool for predicting the risk of alien plant invasions at a global scale. Global Change Biology 11:2234-2250.

Tisch, E. 1992. Alien weed threatens Olympic National Park. Voice of the Wild Olympics: Newsletter of the Olympic Park Associates 1:6.

Tofts, R. J. 2004. Geranium robertianum L. Journal of Ecology 92:537-555.

Tsoar, A., O. Allouche, O. Steinitz, D. Rotem, and R. Kadmon. 2007. A comparative evaluation of presence-only methods for modelling species distribution. Diversity and Distributions 13:397-405.

Underwood, E. C., R. Klinger, and P. E. Moore. 2004. Predicting patterns of non-native plant invasions in Yosemite National Park, California, USA. Diversity and Distributions 10:447459.

Van Ruremonde, R., and J. T. R. Kalkhoven. 1991. Effects of woodlot isolation on the dispersion of plants with fleshy fruits. Journal of Vegetation Science 2:377-384.

Vitousek, P. M., C. M. D'Antonio, L. L. Loope, M. Rejmanek, and R. Westbrooks. 1997. Introduced species: A significant component of human-caused global change. New Zealand Journal of Ecology 21:1-16.

Weber, E. 2003. Invasive plant species of the world: a reference guide to environmental weeds. CABI Publishing, Oxon, UK.

Welk, E. 2004. Constraints in range predictions of invasive plant species due to non-equilibrium distribution patterns: Purple loosestrife (Lythrum salicaria) in North America. Ecological Modelling 179:551-567.

Wieman, J. S. 1961. History of English holly (Ilex aquifolium) in Oregon and the Northwest. J.S. Wieman, Portland, Oregon, USA.

Wilcove, D. S., D. Rothstein, J. Dubrow, A. Phillips, and E. Losos. 1998. Quantifying threats to imperiled species in the United States. Bioscience 48:607-615.

Wisz, M. S., R. J. Hijmans, J. Li, A. T. Peterson, C. H. Graham, and A. Guisan. 2008. Effects of sample size on the performance of species distribution models. Diversity and Distributions 14:763-773. 
Zhu, L., O. J. Sun, W. G. Sang, Z. Y. Li, and K. P. Ma. 2007. Predicting the spatial distribution of an invasive plant species (Eupatorium adenophorum) in China. Landscape Ecology 22:1143-1154. 
TABLE 1. Percent suitable habitat, Sensitivity (proportion of true positives accurately predicted by a model), and accuracy (TSS) of invaded- and native-range models for Geranium robertianum, Hedera helix, and Ilex aquifolium.

\begin{tabular}{|c|c|c|c|c|c|c|}
\hline & \multicolumn{2}{|c|}{ — Geranium - } & \multicolumn{2}{|c|}{ - Hedera - } & \multicolumn{2}{|c|}{ - Ilex- } \\
\hline & $\begin{array}{c}\text { Invaded- } \\
\text { range }\end{array}$ & $\begin{array}{c}\text { Native- } \\
\text { range }\end{array}$ & $\begin{array}{l}\text { Invaded- } \\
\text { range }\end{array}$ & $\begin{array}{c}\text { Native- } \\
\text { range }\end{array}$ & $\begin{array}{c}\text { Invaded- } \\
\text { range }\end{array}$ & $\begin{array}{c}\text { Native- } \\
\text { range }\end{array}$ \\
\hline Percent suitable habitat & 58.3 & 100.0 & 58.8 & 85.6 & 52.0 & 88.8 \\
\hline Sensitivity & 0.90 & 1.00 & 1.00 & 1.00 & 1.00 & 1.00 \\
\hline Accuracy (TSS) & 0.28 & 0.00 & 0.37 & 0.04 & 0.47 & 0.01 \\
\hline
\end{tabular}


TABle 2. Percentages of the Olympic Peninsula and Olympic National Park (ONP) in different categories of near- and long-term invasion risk for Geranium robertianum, Hedera helix, and Ilex aquifolium.

\begin{tabular}{lrrrrrrr} 
& \multicolumn{3}{c}{ - Geranium -} & \multicolumn{3}{c}{ - Hedera -} & \multicolumn{2}{c}{ Ilex - } \\
Invasion risk & Peninsula & ONP & Peninsula & ONP & Peninsula & ONP \\
\hline Minimal & 0.04 & 0.1 & 14.4 & 37.6 & 11.2 & 33.5 \\
Low near term, moderate long term & 40.8 & 77.6 & 26.2 & 40.6 & 36.0 & 50.5 \\
Low near term, high long term & 40.0 & 17.5 & 23.4 & 13.5 & 19.8 & 8.4 \\
Moderate near term, high long term & 10.7 & 3.7 & 22.5 & 4.5 & 15.9 & 3.6 \\
High near term, high long term & 8.5 & 1.1 & 13.4 & 3.8 & 17.2 & 4.0 \\
\hline
\end{tabular}




\section{FigURE CAPTIONS}

FIG. 1. The Olympic Peninsula, Washington, U.S.A. Shading indicates the location of Olympic National Park. Filled circles indicate the locations of sample points. Projection coordinate system for all maps is NAD 1983 UTM Zone 10N.

FIG. 2. Habitat suitability maps for Geranium robertianum using (A) logistic regression (LR), (B) GARP, (C) ENFA, and (D) continental-scale, climate-envelope models. For (A-C), darker shading indicates greater suitability over a range of $0-100$. In (D), dark gray indicates suitable habitat based on native-range and invaded-range models, medium gray indicates suitable habitat based on the native-range model only, and light gray indicates unsuitable habitat. Open circles indicate where Geranium is present.

FIG. 3. Habitat suitability maps for Hedera helix. See Fig. 2 for details.

FIg. 4. Habitat suitability maps for Ilex aquifolium. See Fig. 2 for details.

FIG. 5. Habitat suitability and threshold scores for the three-local scale modeling techniques and for comparison, ensemble models. (A) Mean suitability of all grid cells on the Peninsula. (B) Percent of total habitat area predicted to be suitable using (C) the threshold that maximized TSS. Error bars are $+1 \mathrm{SE}(n=5)$. $F$ and $P$ values for habitat suitability are from one-way ANOVA of the three local-scale models only; different lower-case letters indicate significant differences between model types based on Bonferroni tests of means.

FIG. 6. Model accuracy (AUC and TSS) and agreement (Kappa) for the three local-scale modeling techniques and, for comparison, ensemble models. (A) AUC is threshold independent: values $>0.9$ are considered good, 0.7-0.9 moderate, and $<0.7$ poor (Pearce and Ferrier 2000). (B) TSS is threshold dependent: values $>0.6$ are considered good, $0.2-0.6$ moderate, and $<0.2$ poor (Landis and Koch 1977). (C) Agreement (Kappa) is the mean similarity among all possible pairs of replicates of the same model type $(n=10)$. See Fig. 5 for other details.

FIG. 7. Classification of near- and long-term invasion risk for (A) Geranium robertianum, (B) Hedera helix, and (C) Ilex aquifolium on the Olympic Peninsula. Near-term risk is based on local-scale models and long-term risk, on native- and invaded-range models (see Methods: Combining models from multiple scales). 
FIG. 1.

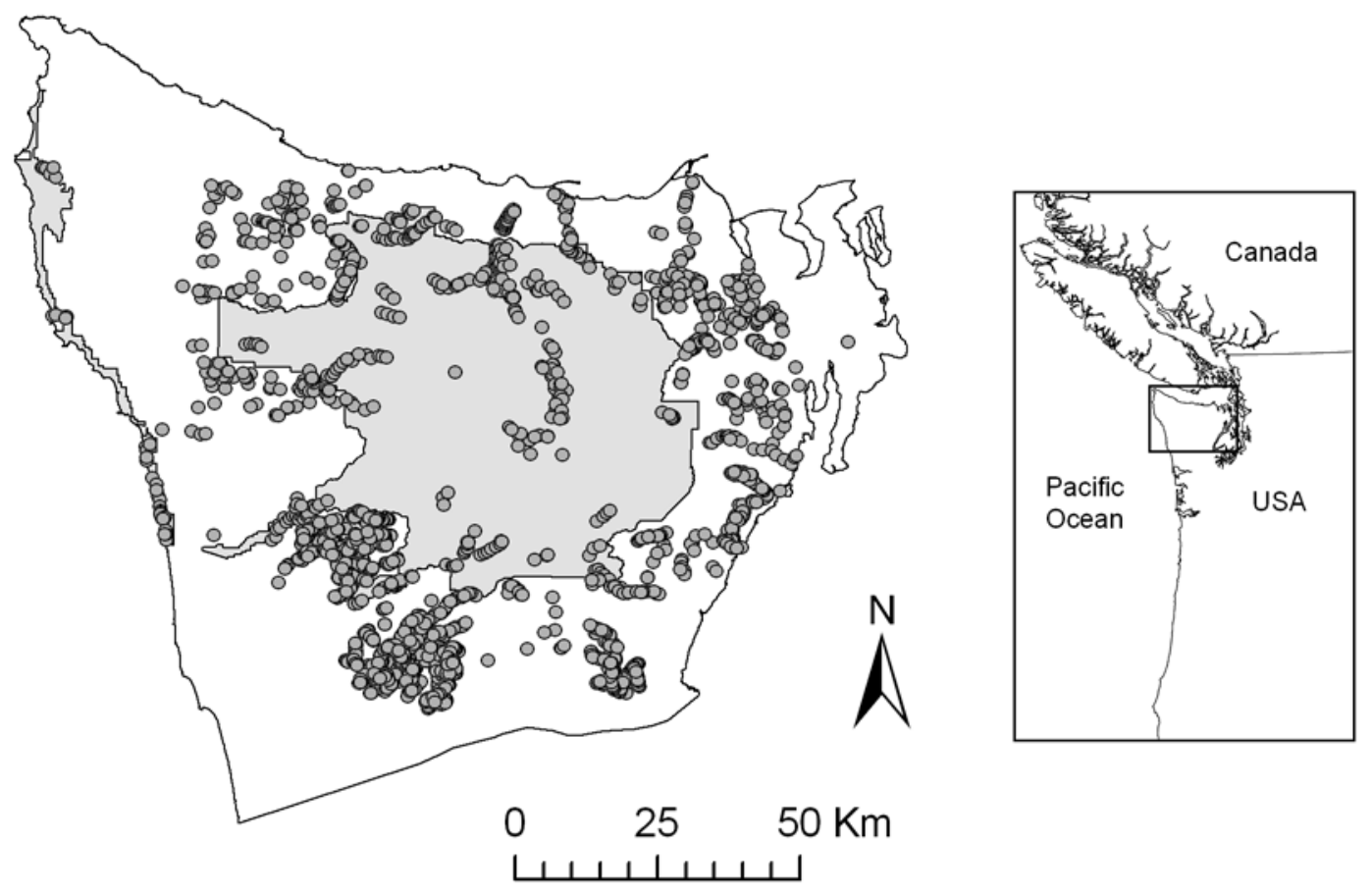


FIG. 2.
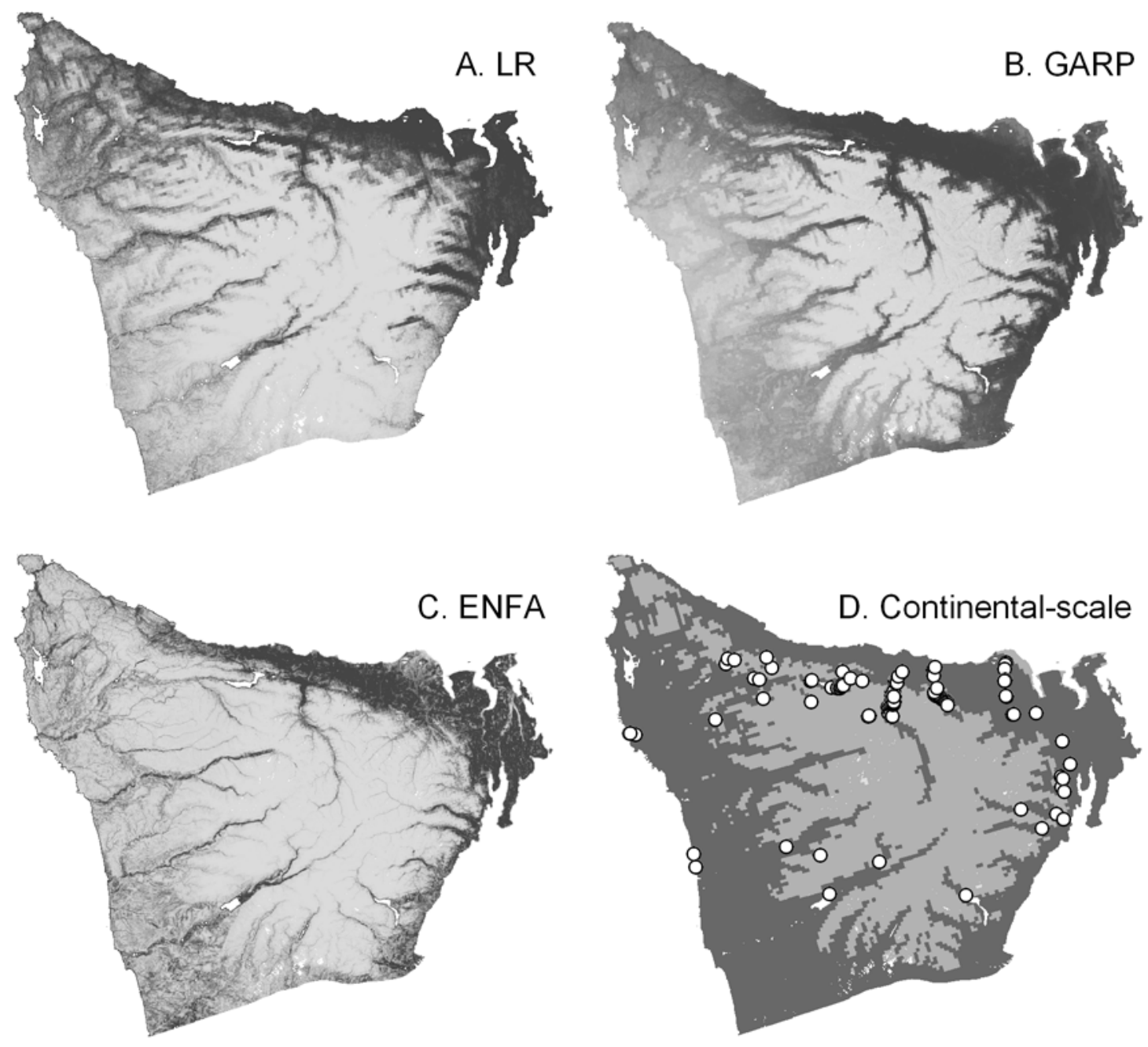
FIG. 3.
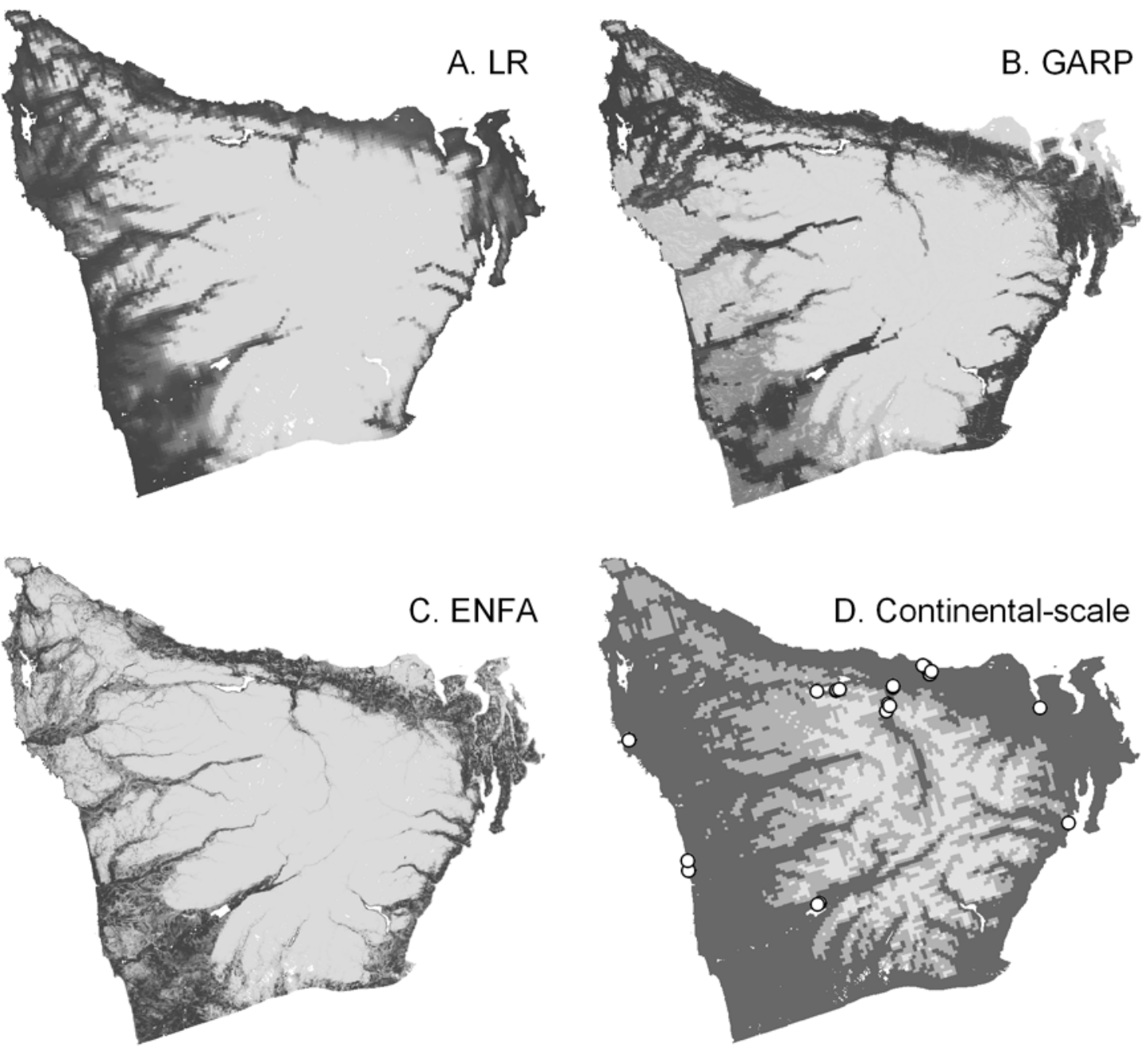
FIG. 4.
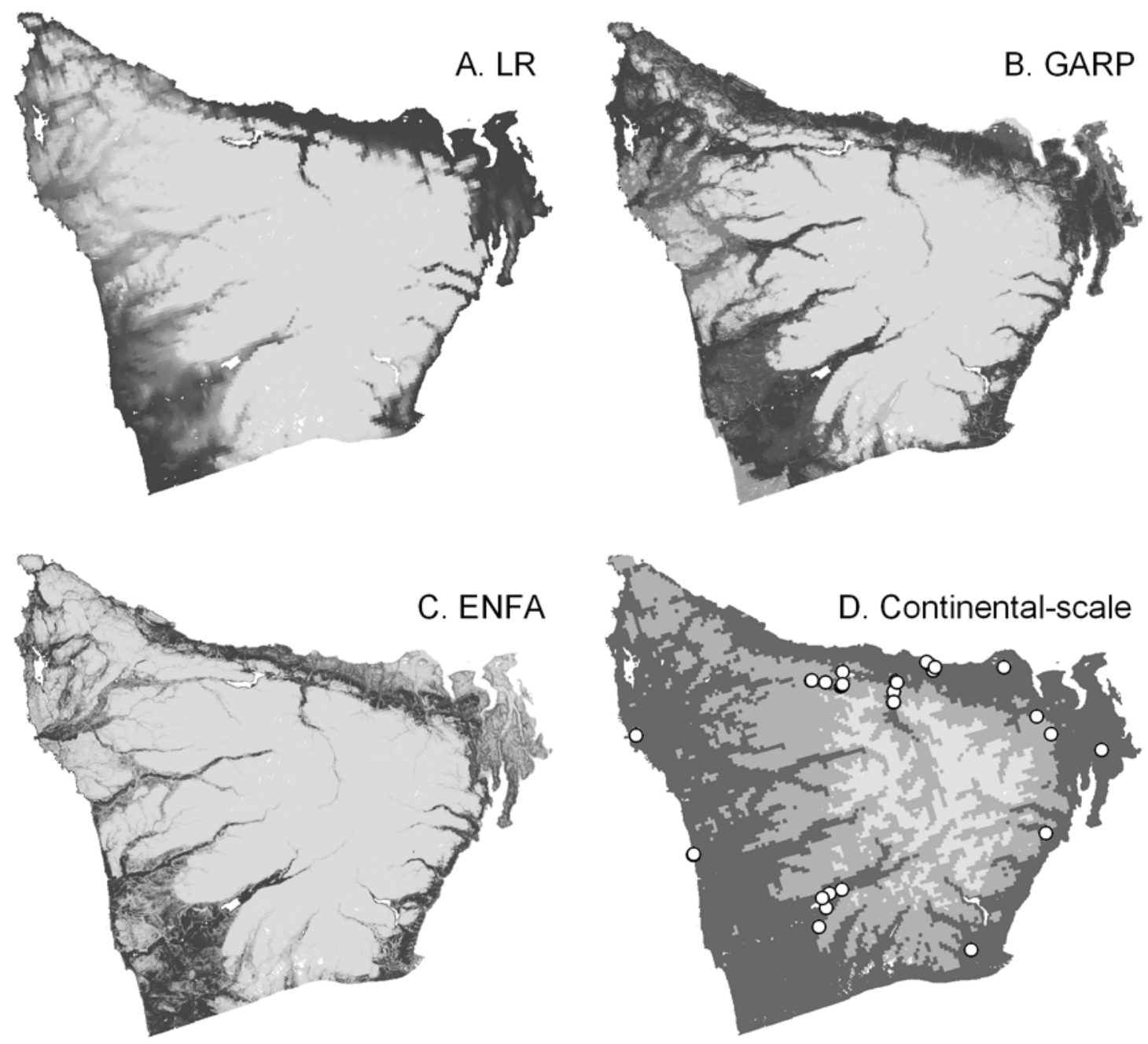
FIG. 5
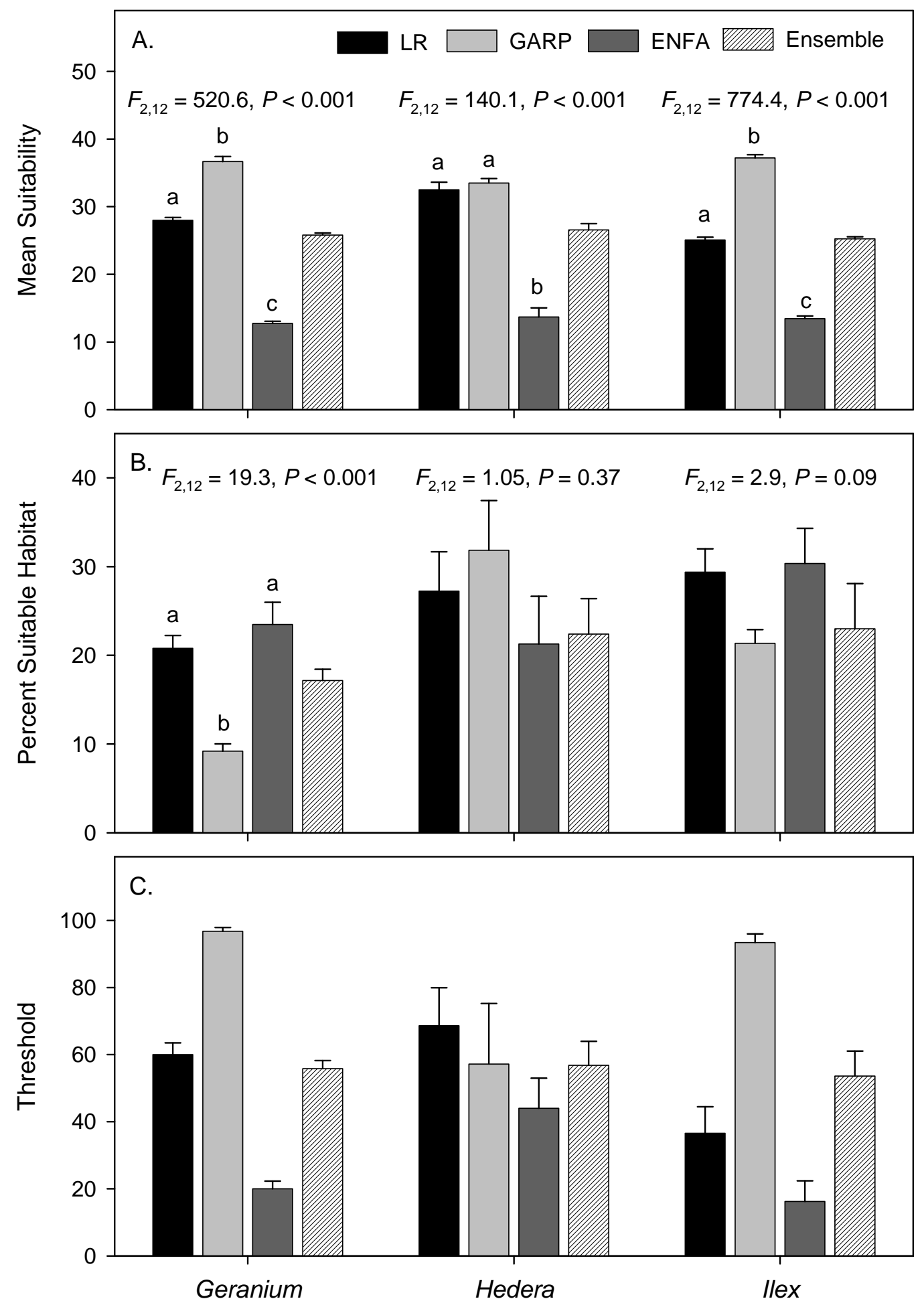
FIG. 6
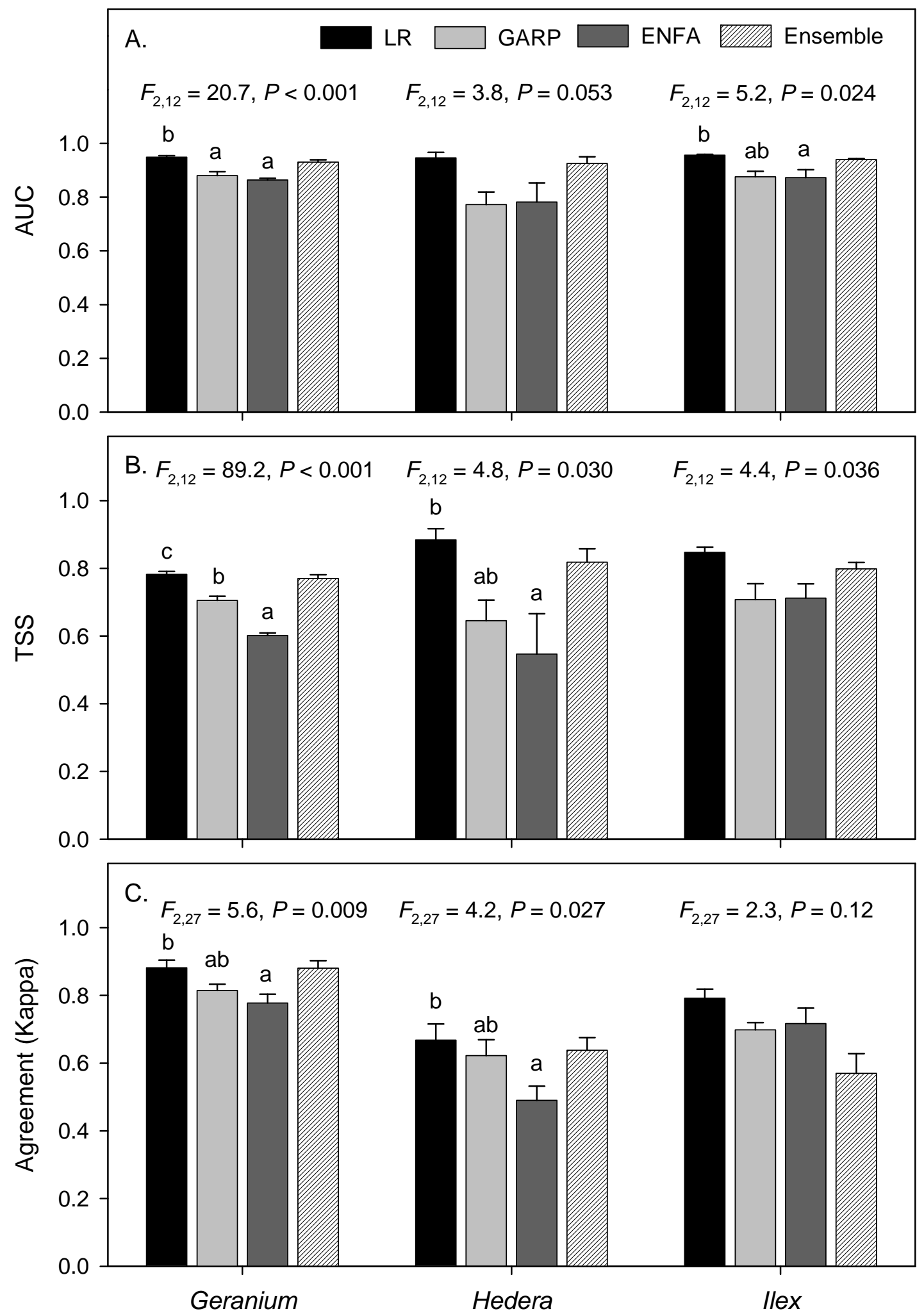
FIG. 7.
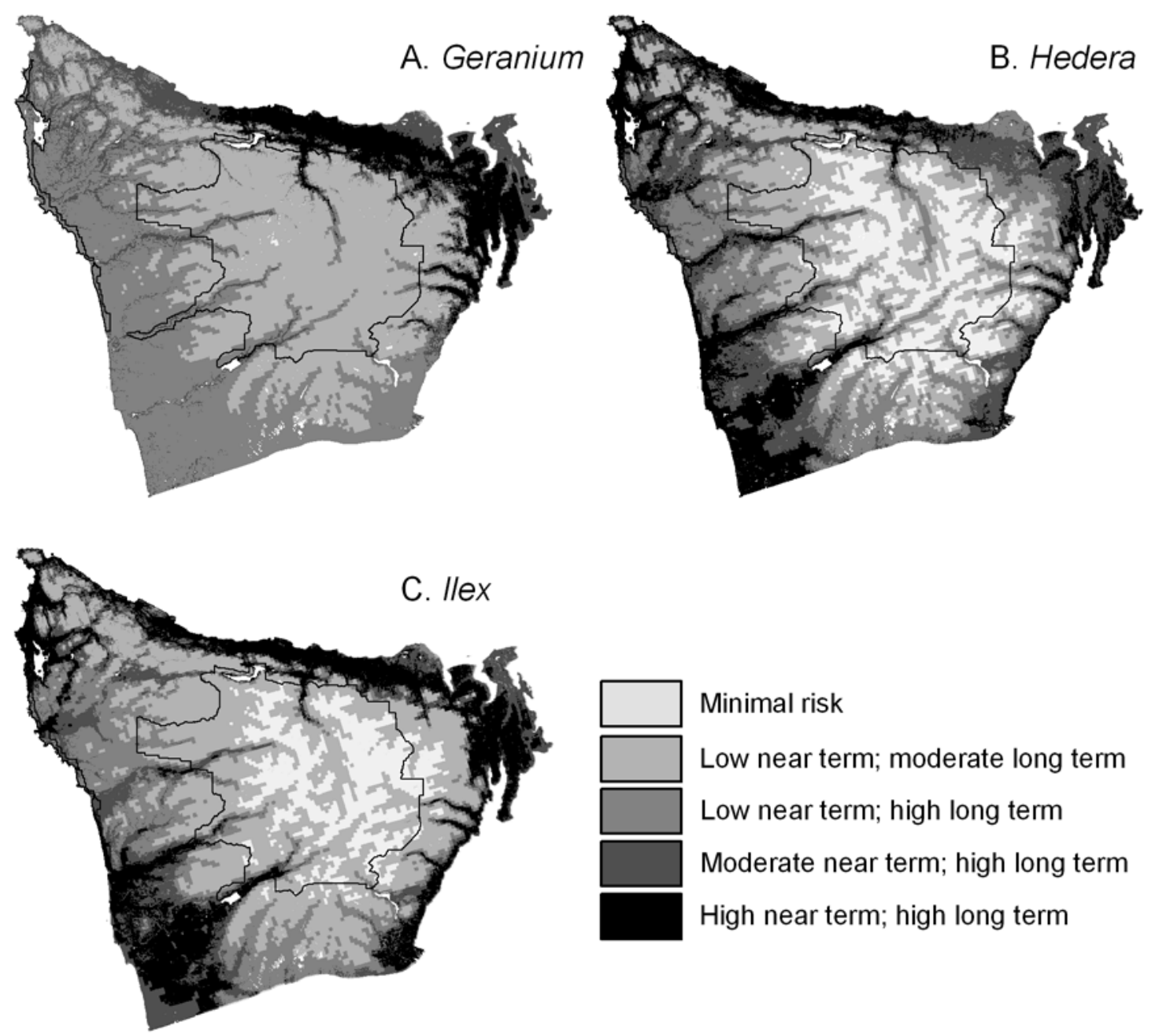

Minimal risk

Low near term; moderate long term Low near term; high long term Moderate near term; high long term High near term; high long term 
Appendix A. Descriptions of species datasets used in modeling.

TABLE A.1. Summary of datasets used.

\begin{tabular}{|c|c|c|c|c|}
\hline Dataset & $\begin{array}{c}\text { Contains } \\
\text { absence } \\
\text { data? }\end{array}$ & $\begin{array}{c}\text { No.of } \\
\text { sample } \\
\text { points }\end{array}$ & $\begin{array}{l}\text { Plot area } \\
\left(\mathrm{m}^{2}\right)\end{array}$ & Dates sampled \\
\hline Olympic National Park Exotics Inventory ${ }^{2}$ & Y & 247 & 100 & 2001 \\
\hline Elwha River Restoration Area Exotics Survey ${ }^{2}$ & $\mathrm{~N}$ & 290 & $\mathrm{n} / \mathrm{a}$ & 2001 \\
\hline \multicolumn{5}{|l|}{ Alpine and Subalpine Plant Community Survey } \\
\hline Plots $^{3}$ & $\mathrm{Y}$ & 12 & $\sim 100$ & 1990, 1999 \\
\hline \multicolumn{5}{|l|}{ Olympic National Park Exotic Plant } \\
\hline Management Team Data² & $\mathrm{N}$ & 65 & $\mathrm{n} / \mathrm{a}$ & 2002-2004 \\
\hline LTEM Elwha Vegetation Survey $^{2}$ & $\mathrm{Y}$ & 61 & $400-625$ & $1999-2000$ \\
\hline Collette DeFerrari Dataset $^{4}$ & $\mathrm{Y} / \mathrm{N}$ & 76 & $50-100$ & 1992 \\
\hline Ann Lezberg Dataset ${ }^{5}$ & $\mathrm{Y}$ & 100 & 100 & 1996-1997 \\
\hline Olympic National Forest Exotics Survey ${ }^{2}$ & $\mathrm{Y}$ & 2832 & $400-2500$ & $1995-2003$ \\
\hline Olympic Habitat Development Study ${ }^{6}$ & $\mathrm{Y}$ & 60 & 100 & $2000-2004$ \\
\hline Olympic National Forest Ecology Plots ${ }^{7}$ & $\mathrm{Y}$ & 21 & $250-1600$ & $1980-2003$ \\
\hline \multicolumn{5}{|l|}{ Vegetation and Landform Database } \\
\hline Development Study ${ }^{2}$ & $\mathrm{~N}$ & 1 & $\sim 100$ & 1997 \\
\hline Olympic National Park Herbarium Records ${ }^{2}$ & $\mathrm{~N}$ & 5 & $\mathrm{n} / \mathrm{a}$ & 1977-1983 \\
\hline Personal Observations ${ }^{2}$ & $\mathrm{~N}$ & 4 & $\mathrm{n} / \mathrm{a}$ & 2005 \\
\hline
\end{tabular}

${ }^{1}$ Number of plots from this dataset included in the current study

${ }^{2}$ Unpublished data

${ }^{3}$ See appendix A1 and A2 in Houston et al. (1994)

${ }^{4}$ DeFerrari and Naiman (1994)

${ }^{5}$ Lezberg et al. (2001)

${ }^{6}$ See Carey and Harrington (2001) and Reutebuch et al. (2004)

${ }^{7}$ Henderson et al. (1989)

\section{DESCRIPTIONS OF DATASETS}

\section{Olympic National Park Exotics Inventory}

The objectives of this inventory were to determine the distribution of exotic species within Olympic National Park and to identify the habitats most susceptible to invasion. Sampling was conducted in four types of areas: developed sites, and along roads, trails, and rivers. Developed sites and road, trail, or river segments were randomly chosen from all those within ONP and multiple plots were systematically sampled within each area or segment. All plots were $100 \mathrm{~m}^{2}$ but of differing shape. Plots in developed sites were $10 \mathrm{x}$ $10 \mathrm{~m}$. Plots along roads and trails were 1 x $100 \mathrm{~m}$ (located along the trail or road edge). Plots along rivers varied in shape to include only riparian vegetation. In each plot, presence of all exotic species was recorded. For the current study, 112 plots in 27 developed sites, 76 plots in 18 road segments, 29 plots in 10 trail segments, and 30 plots 
in 9 river segments were included. Data were collected in 2001 and are on file at Olympic National Park Headquarters, Port Angeles, Washington.

\section{Elwha River Restoration Area Exotics Survey}

The objective of this survey was to document the locations and population sizes of exotic plant species within the Elwha River Restoration Area (river miles 5-16). The survey focused on riparian areas (within $50 \mathrm{~m}$ of the river) and developed areas within $1.5 \mathrm{~km}$ of the river (including roads, power line corridors, trails, and administrative sites). Reservoir shorelines were surveyed by boat; other areas were surveyed by foot. The centers of each population of 26 target exotic species within the surveyed area were recorded. Data were collected in 2001. Only species presence was recorded, thus none of these points were used to indicate absence in the current study. Data and additional information are on file at Olympic National Park Headquarters, Port Angeles, Washington.

\section{Alpine and Subalpine Plant Community Survey Plots (Mountain Goat Study)}

These data were collected to characterize and classify vegetation in the summer range of mountain goats in the Olympic Mountains (Houston et al. 1994). Cover for all plant species was estimated in plots ranging from 20 to $100 \mathrm{~m}^{2}$. Sampling areas were based on the summer range of the mountain goats. Within each sampling area, plots were located and sized to characterize areas of homogeneous vegetation. Data were collected from 771 plots in 69 sampling areas between 1981 and 1990. Some of the plots focused on populations of the rare plant, Astragalus cottonii; these plots were also resampled in 1999.

For this project we only used plots that were $100 \mathrm{~m}^{2}$ and sampled since 1990 . In one instance there were two plots within $12 \mathrm{~m}$ of each other totaling $107 \mathrm{~m}^{2}$; this pair was included as a single data point. Contact: Ed Schreiner, USGS Biological Resource Division, Olympic Field Station, Port Angeles, Washington.

\section{Olympic National Park Exotic Plant Management Team Data}

These points indicate infestations of Geranium robertianum, Hedera helix, and Ilex aquifolium located by the Olympic National Park Exotic Plant Management Team. None of these points indicate the absence of any species. Contact: Dan Campbell, North Coast - Cascades Exotic Plant Management Team, Olympic National Park, Port Angeles, Washington.

\section{LTEM Elwha Vegetation Survey}

The objective of this project was to determine if physical characteristics could be used to predict the distribution of plant communities within the Elwha River Valley. Plots were randomly located within the valley, stratified by $500 \mathrm{~m}$ elevation bands and lower, middle or upper reaches of the river. Plots were either $400 \mathrm{~m}^{2}$ or $625 \mathrm{~m}^{2}$ depending on tree density (larger plots where trees were less dense). Cover (\%) of all understory species was recorded. Contact: Andrea Woodward, USGS-FRESC, Seattle, Washington. 
This study examined patterns of exotic species abundance and distribution at multiple spatial scales in the Hoh and Dungeness River watersheds (DeFerrari and Naiman 1994). Plots included both upland and riparian areas. All species (both native and exotic) were identified in plots that were either $50 \mathrm{~m}^{2}$ (riparian plots) or $100 \mathrm{~m}^{2}$ (upland plots). For this project plots were geo-referenced based on hand drawn maps. We verified locations based on recorded elevation, slope, aspect, and distance to the nearest road or trail; plots that could not be accurately verified to within $50 \mathrm{~m}$ were excluded in the current study (resulting in 10 riparian and 66 upland plots). Because of their small size, riparian plots were used to indicate presence of a target species (not presence-absence).

\section{Ann Lezberg Dataset}

This study compared the development of understory vegetation and overstory structure among four age classes of low elevation forests on the Olympic Peninsula with a focus on the relationships between plant morphological characteristics and overstory structure (Lezberg et al. 2001). Understory data were collected in four to six $100 \mathrm{~m}^{2}$ plots in each of 20 forest stands on the western Olympic Peninsula.

\section{Olympic National Forest Exotic Inventory}

This project was designed by the Olympic National Forest to assess the distribution and abundance on exotic species in the forest, with an emphasis on roadside habitat. There were a total of 3193 plots sampled between 1995 and 2003. There are three major plot types: 1) $400 \mathrm{~m}^{2}$ circular plots, 2) plots encompassing road segments that are $\sim 12 \mathrm{~m}$ wide and 150-200 m long and 3) irregular polygons ranging in size from $200 \mathrm{~m}^{2}$ to 40 ha. The presence or absence of the target invasive species was recorded in each of these plots. For the current project we eliminated all plots greater than $2500 \mathrm{~m}^{2}$, which left 2881 plots. Contact: Joan Ziegltrum, Olympic National Forest, Olympia, Washington.

\section{Olympic Habitat Development Study}

This dataset is from a large-scale silvicultural experiment conducted by the USDA Forest Service in Olympic National Forest. The project assessed the effects of variabledensity thinning in mid-rotation forests on animals, understory vegetation, and canopy structure (Reutebuch et al. 2004). Plots were assigned to treatment or control and $100 \mathrm{~m}^{2}$ subplots were used to measure the understory. Eight sites were located throughout Olympic National Forest (Carey and Harrington 2001). Vegetation was sampled at two sites in 2002 (3 years after treatment) and two additional sites in 2004 (7 years after treatment). Pretreatment data were not available at the necessary scale. To avoid effects of the experimental treatments, we only included untreated subplots. Contact: Leslie Brodie, Forestry Sciences Laboratory, USDA Forest Service, Olympia, Washington.

\section{Olympic National Forest Ecology Plots}

These plots were used to classify and describe the forested plant associations of the Olympic National Forest (Henderson et al. 1989). Plots were distributed throughout the National Forest and ranged in size from 250 to $\sim 1600 \mathrm{~m}^{2}$. Most plots were sampled between 1980 and 1986, although some were resampled as recently as 2003. We only 
included 21 plots where one of the target species was present. Contact: Robin Lesher, Mt. Baker-Snoqualmie National Forest Headquarters, Everett, Washington.

\section{Vegetation and Landform Database Development Study}

The objective of these plots was to assess the accuracy of vegetation classification maps based on satellite imagery for Olympic National Park. Understory vegetation was sampled in $1 / 40^{\text {th }}$-acre plots $\left(\sim 101 \mathrm{~m}^{2}\right)$. Plots were systematically placed along 1.5 mile long transects, located to best capture variation in the vegetation of ONP. Species with $<5 \%$ were not consistently recorded; thus, only plots in which the target species were recorded as present were included in the current study (one plot). Data are on file at Olympic National Park Headquarters, Port Angeles, Washington.

\section{ONP Herbarium Specimen Records}

We included locations where specimens of the three target species were collected for the Olympic National Park Herbarium. We included locations only if they could be georeferenced to within $50 \mathrm{~m}$ (five points). Data and specimens are on file at Olympic National Park Headquarters, Port Angeles, Washington.

\section{Personal Observations}

These points are locations on the Olympic Peninsula where the authors personally observed the species (four points).

\section{LiTERATURE CiTED}

Houston, D. B., E. G. Schreiner, and B. B. Moorhead. 1994. Mountain goats in Olympic National Park: biology and management of an introduced species. Scientific Monograph NPS/NROLYM/NRSM-94/25.

DeFerrari, C. M., and R. J. Naiman. 1994. A multi-scale assessment of the occurrence of exotic plants on the Olympic Peninsula, Washington. Journal of Vegetation Science 5:247-258.

Lezberg, A. L., C. B. Halpern, and J. A. Antos. 2001. Clonal development of Maianthemum dilatatum in forests of differing age and structure. Canadian Journal of Botany 79:1028-1038.

Carey, A. B., and C. A. Harrington. 2001. Small mammals in young forests: implications for management for sustainability. Forest Ecology and Management 154:289-309.

Reutebuch, S. E., C. A. Harrington, D. D. Marshall, and L. C. Brodie. 2004. Use of largescale silvicultural studies to evaluate management options in Pacific Northwest forests of the United States. Forest Snow and Landscape Research 78 (1-2):191-208

Henderson, J. A., D. H. Peter, R. D. Lesher, and D. C. Shaw. 1989. Forested plant associations of the Olympic National Forest. USDA Forest Service Region 6 Ecology Technical Paper 001-88. 
Appendix B. Descriptions of habitat layers used in modeling.

TABLE B.1. Habitat variables considered in models ${ }^{1}$.

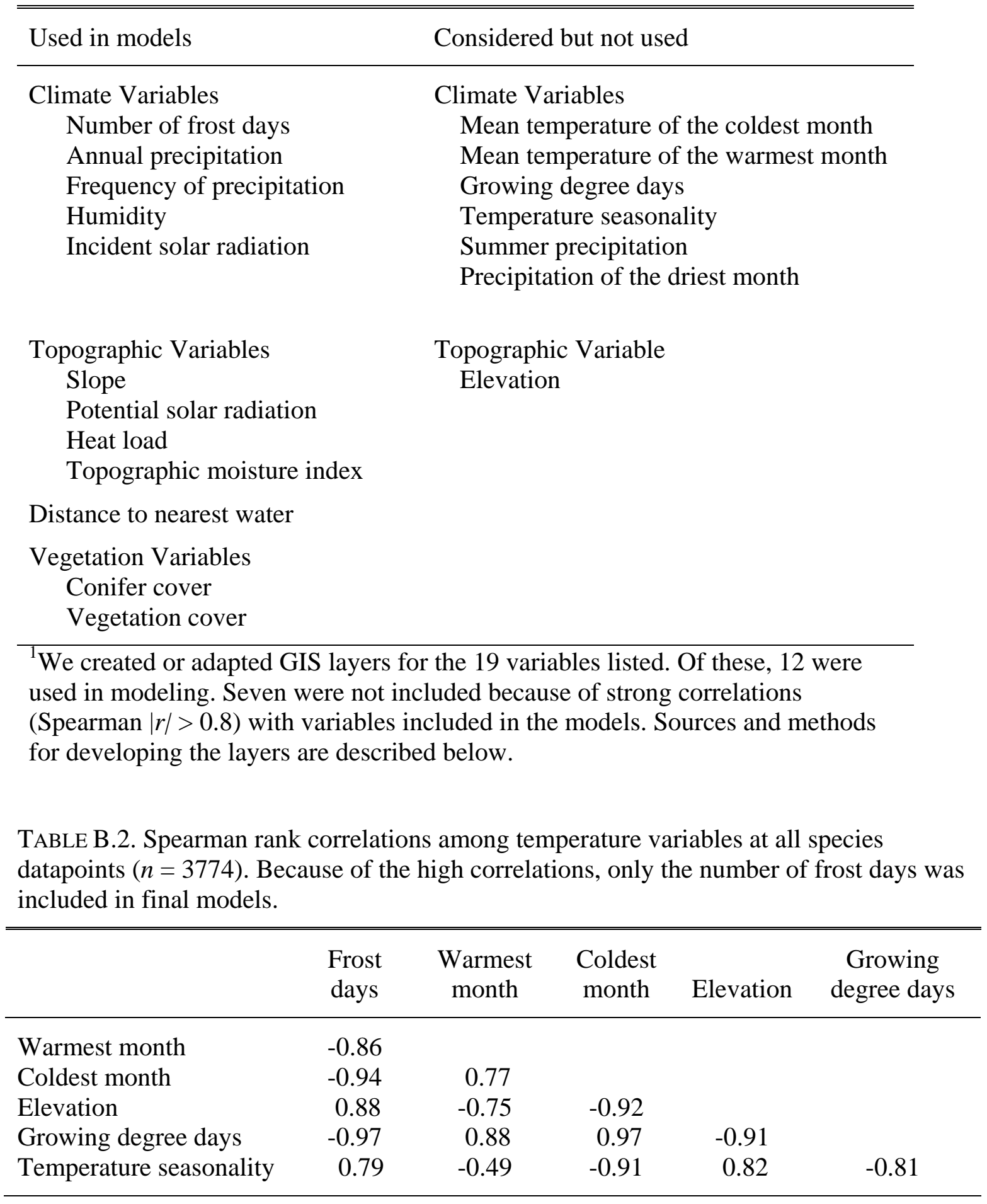

TABLE B.3. Spearman rank correlations among precipitation variables at all species datapoints $(n=3774)$. Because of the 
high correlations, only annual precipitation was included in the models.

$\begin{array}{cc}\text { Precipitation of } & \text { Annual } \\ \text { the driest month } & \text { precipitation }\end{array}$

\begin{tabular}{lll}
\hline Annual precipitation & 0.97 & \\
Summer precipitation & 0.99 & 0.99 \\
\hline
\end{tabular}

TABLE B.4. Spearman rank correlations among variables used in the model at all species datapoints $=3774)$.

\begin{tabular}{|c|c|c|c|c|c|c|c|c|c|c|c|}
\hline & $\begin{array}{l}\text { Distance } \\
\text { to water }\end{array}$ & $\begin{array}{l}\text { Heat } \\
\text { load }\end{array}$ & $\begin{array}{l}\text { Ann. } \\
\text { precip. }\end{array}$ & $\begin{array}{l}\text { Precip. } \\
\text { freq. }\end{array}$ & Slope & $\begin{array}{l}\text { Pot. } \\
\text { rad. }\end{array}$ & $\begin{array}{c}\text { Frost } \\
\text { days }\end{array}$ & $\begin{array}{c}\text { Incid. } \\
\text { rad. }\end{array}$ & TMI & Hum. & $\begin{array}{c}\text { Conifer } \\
\text { cover }\end{array}$ \\
\hline Heat load & -0.04 & & & & & & & & & & \\
\hline $\begin{array}{l}\text { Annual } \\
\text { precipitation }\end{array}$ & 0.04 & 0.17 & & & & & & & & & \\
\hline $\begin{array}{l}\text { Precipitation } \\
\text { frequency }\end{array}$ & 0.07 & 0.11 & 0.62 & & & & & & & & \\
\hline Slope & 0.00 & 0.20 & 0.46 & 0.00 & & & & & & & \\
\hline $\begin{array}{l}\text { Potential } \\
\text { radiation }\end{array}$ & -0.04 & 0.61 & 0.18 & 0.09 & 0.23 & & & & & & \\
\hline Frost days & 0.07 & 0.16 & 0.78 & 0.10 & 0.62 & 0.17 & & & & & \\
\hline $\begin{array}{l}\text { Incident solar } \\
\text { radiation }\end{array}$ & -0.03 & 0.06 & -0.14 & 0.02 & -0.14 & 0.18 & -0.25 & & & & \\
\hline $\begin{array}{l}\text { Topographic } \\
\text { moisture index } \\
\text { (TMI) }\end{array}$ & -0.09 & -0.12 & -0.40 & -0.11 & -0.63 & -0.16 & -0.45 & 0.06 & & & \\
\hline Humidity & -0.13 & -0.09 & -0.49 & 0.01 & -0.44 & -0.10 & -0.72 & 0.19 & 0.33 & & \\
\hline Conifer cover & 0.19 & 0.12 & 0.14 & 0.14 & 0.05 & -0.13 & 0.12 & -0.02 & -0.08 & -0.11 & \\
\hline Vegetation cover & 0.05 & 0.04 & 0.00 & 0.12 & -0.09 & -0.10 & -0.09 & 0.00 & 0.04 & 0.06 & 0.46 \\
\hline
\end{tabular}

\section{Climate VARiables}

All of the following climate layers were developed by the Numerical Terradynamic Simulation Group at the University of Montana using the DAYMET model (www.daymet.org, Thornton et al. 1997). The model is based on a digital elevation model and observations from meteorological stations over an 18-year period (1980-1997). The grids have a $1 \mathrm{~km}$ resolution for the contiguous USA. Original projection: Lambert Equal-Area Azimuthal (central meridian -100; central parallel 45).

We clipped all climate layers to a rectangle encompassing the Olympic Peninsula, reset the cell size to $25 \mathrm{~m}$ and re-projected them to UTM Zone 10 NAD 1983. Changing the cell size to $25 \mathrm{~m}$ prior to projection reduced the distortion caused by projecting a grid. 
Number of frost days - number of days in the year with average minimum temperatures of $0^{\circ} \mathrm{C}$ or less.

Annual precipitation - sum of the monthly precipitation over the entire year.

Frequency of precipitation - proportion of days with $>0$ precipitation.

Humidity - average over the year of the daily partial pressure of water vapor near the surface. Humidity was modeled based on precipitation and temperature values (Thornton et al. 1999, 2000).

Incident solar radiation - annual average of the daily total shortwave radiation flux as estimated based on temperature, precipitation and humidity values (Thornton et al. 1999, Thornton et al. 2000).

Mean temperature of the coldest month - mean daily temperature for the coldest month (December for all grid cells).

Mean temperature of the warmest month - mean daily temperature for the warmest month (August for all grid cells).

Growing degree days - sum of daily mean temperatures for all days in the year with mean temperatures above $0^{\circ} \mathrm{C}$.

Temperature seasonality - difference between the mean temperature of the warmest month and the mean temperature of the coldest month, calculated for each cell.

Summer precipitation - sum of the monthly precipitation for July to September.

Precipitation of the driest month - mean precipitation for the month with lowest precipitation (July or August depending on location).

\section{TOPOGRAPHIC VARIABLES}

Topographic variables are based on the USGS Digital Elevation Model (DEM), accessed via the University of Washington:

http://duff.geology.washington.edu/data/raster/tenmeter/onebytwo10/index.html. Original projection: Zone 10 NAD 1927 (converted to NAD 1983).

\section{Variable descriptions}

Elevation - we resampled the original $10 \mathrm{~m}$ DEM to $25 \mathrm{~m}$ using bilinear interpolation.

Slope - we used ArcView 3.2 to create a slope grid based on the $10 \mathrm{~m}$ DEM and resampled to $25 \mathrm{~m}$ using linear interpolation.

Topographic moisture index - calculated for each grid cell as $\ln (\mathrm{A} / \tan \mathrm{B})$ where $\mathrm{A}$ is the catchment area or the area from which water will flow to the selected grid cell, and $\mathrm{B}$ is the slope of the grid cell (Moore et al. 1993). An ArcView extension for calculating this index was obtained from Tim Loesch, Minnesota DNR www.dnr.state.min.us/mis/gis/tools/arcview/training.html.

Potential solar radiation - calculated from slope, aspect, and latitude (to the nearest 0.001 degree) of each $10 \mathrm{~m}$ cell using equations from McCune and Keon (2002). We then resampled to $25 \mathrm{~m}$ using bilinear interpolation.

Heat load - similar to potential solar radiation (and developed using the same procedure), but it reaches its maximum on southwest rather than south-facing slopes. 


\section{DISTANCE TO NEAREST WATER}

This variable was based on the combination of two layers: (1) a wetlands layer from the National Wetland Inventory (www.nwi.fws.gov) via the ONRC Clearinghouse http://www.onrc.washington.edu/clearinghouse/themes/hydro/hydro_theme.html. Original projection: UTM Zone 10 NAD 1927. Wetland polygons were classified by hierarchical wetland type. We removed all upland polygons and all marine areas that are continuously flooded (M1OWL and E10WL); and (2) a layer containing all stream segments on the Olympic Peninsula from Olympic National Forest (http://www.fs.fed.us/r6/data-library/gis/olympic/index.html). Original projection: UTM Zone 10 NAD 1927. Both layers were converted to NAD 1983.

\section{Variable descriptions}

Distance to water - the base-10 logarithm of the distance to the nearest wetland or stream. Distance was log transformed because differences over the first $50 \mathrm{~m}$ are likely to be the most important.

\section{VEGETATION VARIABLES}

We used vegetation data from the Interagency Vegetation Mapping Project (IVMP; http://www.blm.gov/or/gis/index.php). Original Projection: UTM Zone 10 NAD 1927 (converted to NAD 1983). We used two different layers: vegetation cover and conifer cover. About $2 \%$ of cells are classified as "unknown" because of topographic shadow, smoke, clouds, or other problems in the images; these were removed from the study. Remote sensing data are Landsat 5 TM images from 1996.

\section{Variable descriptions}

Conifer cover - We used the conifer cover layer from IVMP. We converted this layer into 6 classes: $0=0 \%$ conifer cover (or classified as non-forested), $1=1-20 \%$ cover, $2=21-40 \%$ cover, $3=41-60 \%$ cover, $4=61-80 \%$ cover and $5=81-100 \%$ cover. Accuracy for conifer cover using these cover classes was $64.6 \%$.

Vegetation cover - We used the vegetation cover layer from IVMP, which measures all vegetation (herbs, shrubs, deciduous trees, and coniferous trees). We divided cover values into the same categories as used for the conifer cover layer. Accuracy was 87.9\%.

\section{LITERATURE CITED}

McCune, B., and D. Keon. 2002. Equations for potential annual direct incident radiation and heat load. Journal of Vegetation Science 13:603-606.

Moore, I. D., P. E. Gessler, G. A. Nielsen, and G. A. Peterson. 1993. Soil attribute prediction using terrain analysis. Soil Science Society of America Journal 57:443452.

Thornton, P. E., H. Hasenauer, and M. A. White. 2000. Simultaneous estimation of daily solar radiation and humidity from observed temperature and precipitation: an 
application over complex terrain in Austria. Agricultural and Forest Meteorology 104:255-271.

Thornton, P. E., S. W. Running, and M. A. White. 1997. Generating surfaces of daily meteorological variables over large regions of complex terrain. Journal of Hydrology 190:214-251.

Thornton, P. E., and S. W. Running. 1999. An improved algorithm for estimating incident daily solar radiation from measurements of temperature, humidity and precipitation. Agricultural and Forest Meteorology 93:211-228. 
Appendix C. Climate variable parameters in climate-envelope models

TABLE C.1. Climate parameters used to develop climate-envelope models. Native-range models are based on data from Europe and invaded-range models based on data from the contiguous U.S.A. Numbers indicate the extreme values for each variable among locations where the species occur after removing the $5 \%$ most extreme values $(2.5 \%$ at each extreme). Min. indicates that the lower extreme was used (all three variables); Max. indicates that the upper extreme was also used (Mean July temperature).

\begin{tabular}{lccccc}
\hline \hline & & $\begin{array}{c}\text { Annual } \\
\text { precipitation, } \\
\text { Model }\end{array}$ & $N$ & $\begin{array}{c}\text { Mean January } \\
\text { temperature, } \\
\text { Min. }(\mathrm{cm})\end{array}$ & \multicolumn{2}{c}{$\begin{array}{c}\text { Mean July } \\
\text { temperature }\left({ }^{\circ} \mathrm{C}\right) \\
\text { Min. }\end{array}$} & Max. \\
\hline $\begin{array}{l}\text { Geranium robertianum } \\
\quad \text { Native-range }\end{array}$ & 1886 & 55.7 & -8.8 & 11.8 & 18.4 \\
$\quad \begin{array}{l}\text { Invaded-range } \\
\text { Hedera helix }\end{array}$ & 93 & 70.5 & -7.7 & 15.5 & 23.5 \\
$\quad$ Native-range & 389 & 48.5 & -3.8 & 14.4 & 25.3 \\
$\quad \begin{array}{l}\text { Invaded-range } \\
\text { Ilex aquifolium }\end{array}$ & 59 & 51.8 & -3.4 & 15.5 & 27.5 \\
$\quad$ Native-range & 183 & 64.7 & -2.9 & 12.7 & 21.7 \\
$\quad$ Invaded-range & 49 & 54.2 & 1.2 & 15.6 & 19.7 \\
\hline
\end{tabular}


Appendix D. Importance of habitat variables in model results

TABLE D.1. Importance of habitat variables in model results. Importance was assessed differently for different model types. LR: number of replicates in which the variable was retained after stepwise removal; values in parentheses are mean regression coefficients (and sign) among replicates. GARP: For each replicate model, we created 50 GARP models with each of the 12 habitat variables removed (600 models/replicate). We then used $t$-tests to compare the accuracy (Sensitivity) of models that included the variable of interest (550 models/replicate) with those in which the variable was removed (50 models/replicate). Values are mean $t$-statistics (and SEs) for the five replicates of each species. The magnitude of a positive mean $t$-statistic reflected the degree to which a variable improved model accuracy. ENFA: mean loading on the first factor, indicating the difference in a variable for points representing species' occurrences and the median of the study area.

\begin{tabular}{|c|c|c|c|c|c|c|c|c|c|}
\hline \multirow[b]{2}{*}{ Habitat variable } & \multicolumn{3}{|c|}{ - Geranium - } & \multicolumn{3}{|c|}{ - Hedera - } & \multicolumn{3}{|c|}{ - Ilex- } \\
\hline & LR & GARP & ENFA & LR & GARP & ENFA & LR & GARP & ENFA \\
\hline Intercept & (25.56) & - & - & $(66.62)$ & - & - & (90.58) & - & - \\
\hline Annual precipitation & $\begin{array}{c}5 \\
(-0.06)\end{array}$ & $\begin{array}{l}-0.03 \\
(0.32)\end{array}$ & -0.55 & & $\begin{array}{c}-0.44 \\
(1.99)\end{array}$ & -0.57 & $\begin{array}{c}4 \\
(0.07)\end{array}$ & $\begin{array}{c}0.40 \\
(1.40)\end{array}$ & -0.55 \\
\hline Conifer cover & $\begin{array}{c}5 \\
(-0.19)\end{array}$ & $\begin{array}{l}-0.05 \\
(0.35)\end{array}$ & -0.25 & & $\begin{array}{c}0.85 \\
(0.67)\end{array}$ & -0.07 & & $\begin{array}{c}0.33 \\
(0.32)\end{array}$ & -0.09 \\
\hline Distance to water & $\begin{array}{c}5 \\
(-0.73)\end{array}$ & $\begin{array}{l}-0.32 \\
(0.31)\end{array}$ & -0.30 & & $\begin{array}{c}0.13 \\
(1.05)\end{array}$ & -0.08 & & $\begin{array}{c}0.82 \\
(0.51)\end{array}$ & -0.09 \\
\hline Frost days & $\begin{array}{c}5 \\
(0.06)\end{array}$ & $\begin{array}{l}-0.62 \\
(0.91)\end{array}$ & -0.30 & $\begin{array}{c}5 \\
(-0.36)\end{array}$ & $\begin{array}{l}1.86 \\
(1.16)\end{array}$ & -0.45 & $\begin{array}{c}5 \\
(-0.43)\end{array}$ & $\begin{array}{l}-1.59 \\
(2.57)\end{array}$ & -0.41 \\
\hline Heat load & & $\begin{array}{l}-0.80 \\
(0.19)\end{array}$ & -0.10 & & $\begin{array}{c}0.73 \\
(0.85)\end{array}$ & -0.01 & & $\begin{array}{l}-0.67 \\
(1.28)\end{array}$ & -0.08 \\
\hline Potential radiation & $\begin{array}{c}1 \\
(-2.25)\end{array}$ & $\begin{array}{l}-0.67 \\
(0.33)\end{array}$ & -0.08 & $\begin{array}{c}1 \\
(18.94)\end{array}$ & $\begin{array}{l}-0.51 \\
(2.37)\end{array}$ & 0.01 & & $\begin{array}{l}-1.69 \\
(0.90)\end{array}$ & -0.07 \\
\hline $\begin{array}{l}\text { Precipitation } \\
\text { frequency }\end{array}$ & $\begin{array}{c}5 \\
(34.9)\end{array}$ & $\begin{array}{c}2.14 \\
(0.76)\end{array}$ & -0.48 & & $\begin{array}{l}-0.05 \\
(1.37)\end{array}$ & -0.24 & $\begin{array}{c}5 \\
(-84.5)\end{array}$ & $\begin{array}{l}2.71 \\
(0.75)\end{array}$ & -0.30 \\
\hline Radiation & $\begin{array}{c}5 \\
(-2.61)\end{array}$ & $\begin{array}{l}-0.86 \\
(0.43)\end{array}$ & 0.01 & $\begin{array}{c}5 \\
(-4.05)\end{array}$ & $\begin{array}{l}-1.53 \\
(2.30)\end{array}$ & 0.13 & $\begin{array}{c}5 \\
(-3.20)\end{array}$ & $\begin{array}{c}0.94 \\
(0.33)\end{array}$ & 0.11 \\
\hline Slope & & $\begin{array}{l}-1.18 \\
(0.59)\end{array}$ & -0.31 & & $\begin{array}{c}0.13 \\
(0.41)\end{array}$ & -0.40 & & $\begin{array}{l}-3.77 \\
(3.05)\end{array}$ & -0.45 \\
\hline Vegetation cover & & $\begin{array}{l}-0.79 \\
(0.33)\end{array}$ & -0.08 & & $\begin{array}{l}-0.01 \\
(0.57)\end{array}$ & -0.22 & & $\begin{array}{l}-0.46 \\
(0.45)\end{array}$ & -0.07 \\
\hline Humidity & $\begin{array}{c}5 \\
(0.002)\end{array}$ & $\begin{array}{c}1.43 \\
(0.33)\end{array}$ & 0.14 & & $\begin{array}{l}-1.37 \\
(1.84)\end{array}$ & 0.32 & $\begin{array}{c}5 \\
(-0.004)\end{array}$ & $\begin{array}{l}-0.65 \\
(0.84)\end{array}$ & 0.28 \\
\hline $\begin{array}{l}\text { Topographic } \\
\text { moisture index }\end{array}$ & & $\begin{array}{c}0.59 \\
(0.44)\end{array}$ & 0.30 & & $\begin{array}{l}-0.83 \\
(2.09)\end{array}$ & 0.22 & & $\begin{array}{c}0.39 \\
(0.60)\end{array}$ & 0.27 \\
\hline Marginality & - & - & 1.17 & - & - & 1.02 & - & - & 1.02 \\
\hline Specialization & - & - & 2.07 & - & - & 6.24 & - & - & 4.39 \\
\hline Residual deviance & 189.66 & - & - & 15.09 & - & - & 27.21 & - & - \\
\hline
\end{tabular}

